\title{
Review \\ Cell-Penetrating Peptides Derived from Animal Venoms and Toxins
}

\author{
Gandhi Rádis-Baptista
}

Citation: Rádis-Baptista, G.

Cell-Penetrating Peptides Derived

from Animal Venoms and Toxins.

Toxins 2021, 13, 147. https://

doi.org/10.3390/toxins13020147

Received: 28 December 2020

Accepted: 9 February 2021

Published: 15 February 2021

Publisher's Note: MDPI stays neutral with regard to jurisdictional claims in published maps and institutional affiliations.

Laboratory of Biochemistry and Biotechnology, Institute for Marine Sciences, Federal University of Ceara, Fortaleza 60165-081, Brazil; gandhi.radis@ufc.br; Tel.: +55-85-996886054

\begin{abstract}
Cell-penetrating peptides (CPPs) comprise a class of short polypeptides that possess the ability to selectively interact with the cytoplasmic membrane of certain cell types, translocate across plasma membranes and accumulate in the cell cytoplasm, organelles (e.g., the nucleus and mitochondria) and other subcellular compartments. CPPs are either of natural origin or de novo designed and synthesized from segments and patches of larger proteins or designed by algorithms. With such intrinsic properties, along with membrane permeation, translocation and cellular uptake properties, CPPs can intracellularly convey diverse substances and nanomaterials, such as hydrophilic organic compounds and drugs, macromolecules (nucleic acids and proteins), nanoparticles (nanocrystals and polyplexes), metals and radionuclides, which can be covalently attached via CPP N- and C-terminals or through preparation of CPP complexes. A cumulative number of studies on animal toxins, primarily isolated from the venom of arthropods and snakes, have revealed the cell-penetrating activities of venom peptides and toxins, which can be harnessed for application in biomedicine and pharmaceutical biotechnology. In this review, I aimed to collate examples of peptides from animal venoms and toxic secretions that possess the ability to penetrate diverse types of cells. These venom CPPs have been chemically or structurally modified to enhance cell selectivity, bioavailability and a range of target applications. Herein, examples are listed and discussed, including cysteine-stabilized and linear, $\alpha$-helical peptides, with cationic and amphipathic character, from the venom of insects (e.g., melittin, anoplin, mastoparans), arachnids (latarcin, lycosin, chlorotoxin, maurocalcine/imperatoxin homologs and wasabi receptor toxin), fish (pardaxins), amphibian (bombesin) and snakes (crotamine and cathelicidins).
\end{abstract}

Keywords: cell-penetrating peptide; venom peptide; arachnid venom peptide; insect venom peptide; snake venom peptide; cellular uptake; peptide chemical modification; peptide engineering; peptide design; peptide carrier

Key Contribution: The previous discoveries and the recent advances in the natural and synthetic peptides derived from animal venoms with multiple effects, especially with membrane-interacting and cell-penetrating activity, have demonstrated the unparalleled potential of venom components for the development of combined therapies and, importantly, for the use of venom peptides as platforms for biopharmaceutical innovation.

\section{Introduction \\ Context}

It has been established that the more diverse a biome is, the more intricate is the chemical-ecological relationships among organisms sharing the same niche and richer is the diversity of molecules and pharmacological activities that these co-inhabiting organisms contain. Indeed, a great probability of success in the drug discovery process from nature is connected to maximal biodiversity and chemical diversity [1].

Animal venoms and skin secretions are rich biological materials that contain a blend of biologically and pharmacologically active components, used by venomous and poisonous 
organisms for defense, predation and territorial disputes. The mechanisms via which these organisms deliver toxic components are related to how toxins have evolved and exerted their ecological functions [2]. As a result of millions of years of evolution, the diversity of molecular structures and activities is immeasurable, with hidden functions and structures only recently disclosed by modern omics techniques associated with classical pharmacological studies [3]. Thus, the holistic molecular genetic analyses of venomous animals utilizing, for example, transcriptome in combination with proteome studies of venom glands, have revealed not only the diversity of a set of substances produced by a given organism that inhabits a particular biome but also the uniqueness of such molecular repertoire expressed as active components of biological materials, such as venoms [4-8].

Although marine and terrestrial biological reservoirs of active venom peptides appear crucial sources for drug discovery, examples of basic and applied research should be provided to attract the attention of the scientific community both in academia and industry. Fundamental research, development and innovation of venom components as diagnostics, therapeutics or both are not always an obvious issue for consideration for the general audience. Furthermore, molecular diversity is intrinsically related to biodiversity and pharmaceutical success in drug discovery from nature is dependent on the abundance and variety of biological resources, thus highlighting arguments for policies of environmental conservation and economic sustainability worldwide [9].

A particular class of molecules from animal venom that has been under constant focus comprises biologically active (bioactive) peptides. Owing to their selectivity for corresponding cell receptors and target specificity, as well as the relative structural stability in body fluids and amenability to be genetically and synthetically engineered, natural venom peptides are promising scaffolds for conversion into biopharmaceuticals (biotherapeutics), as exemplified by cysteine-stabilized and linear helical peptides [10-12]. In this review, I discussed natural peptides from animal venom and their derivatives possessing intrinsic properties such as interaction with biomembranes of target cells, access to the cytoplasm through membrane translocation and eventual accumulation in distinct organelles such as the nucleus and mitochondria. This class of special peptides, collectively called cellpenetrating peptides (CPPs), comprise full sequences, peptide segments or patches of large proteins and even encrypted subcellular localization signals, as well as rationally designed peptide chimeras, cyclic, stapled, dimeric, multivalent and self-assembled peptides and peptoid foldamers [13-15].

In the field of toxicology, membrane translocation and cell-penetration capabilities are well-recognized phenomena mainly associated with microbial and plant toxins, such as binary bacterial toxins (e.g., diphtheria toxin, Shiga toxin and cholera toxin) and plant ribosome inhibitor proteins (e.g., ricin and abrin), which bind to their respective receptors on the eukaryotic cytoplasmic membrane and enter cells by receptor-mediated endocytosis [16-18]. Less common but with a steeply increasing number of reports published over the years, animal toxins and venom peptides endowed with intrinsic properties of membrane permeation and cell internalization are currently being unraveled. These venom CPPs and derivatives, recapitulated herein, mechanistically penetrate cells by distinct pathways that involve receptor-dependent and/or receptor-independent endocytosis (nondisruptive peptides) or direct translocation through pore formation, followed by cellular uptake and intracellular compartmentalization (disruptive peptides). Hence, in this review, I collated current examples of cell-penetrating peptides derived from animal venoms and toxins, their basic research and advanced applications.

Cell-penetrating peptides (CPPs) consist of short sequences that range from few amino acids to less than 40 residues, which owing to their physicochemical and biological properties can cross lipid membranes of cells and intracellularly transport diverse types of molecular cargoes in the form of covalent conjugates or noncovalent complexes. The first CPP sequences were characterized and derived from the transactivator of transcription from HIV-1 (Tat protein), the antennapedia (Antp) homeodomain from Drosophila and VP22 from Herpes simplex virus type I, almost three decades ago. For instance, CPPs such as 
Tat $^{48-60}$ (residues 48-60, GRKKRRQRRRPPQ) and penetratin (Antp ${ }^{43-58}$, RQIKIWFQNRRMKWKK), which are short-derived fragments from TAT protein and Drosophila Antp, respectively, were able to translocate across the plasma membrane of eukaryotic cells and set the stage for the development of a new class of non-viral vectors for the intracellular delivery of compounds and, therefore, converted into archetypal CPPs $[19,20]$. Since these initial discoveries, the field of CPPs has expanded into a prolific field of research. Databases of curated information about experimentally characterized CPPs and algorithms to predict CPPs have been created, along with the expansion of the field of CPPs [21-24]. It has become evident that CPPs are mostly linear sequences but cyclic sequences have also been detected and developed. They are usually composed of positively charged amino acids with or without distributed hydrophobic residues, conferring these peptide structures with a variable but a considerable level of amphipathic and cationicity and high affinity for negatively charged lipid membranes and their components, including phospholipids and proteoglycans. In particular, in the case of linear CPPs, studies investigating the relationship between CPP secondary structures and penetrability have demonstrated that cationic helical peptides possess superior cell permeation than amphipathic helical and amphipathic random peptides, as revealed through synthetic polyarginine CPPs stabilized with different proportion of $\alpha$-aminoisobutyric acid [25]. Nevertheless, unstructured peptides in solution eventually form helices upon interaction with plasma membranes, promoting their efficient membrane insertion, translocation and cellular uptake [26]. Hydrophobic interaction followed by membrane insertion also plays a role in the cell penetration property demonstrated by some amphipathic CPPs [27]. Importantly, from the perspective of applications in biomedicine and pharmaceutical biotechnology, CPPs can simultaneously mediate the intracellular delivery of diverse molecular cargos, along with the membrane-crossing activity. These molecular cargoes include hydrophilic drugs, radionuclides, imaging agents (fluorescent dyes), biopolymers (nucleic acids, polypeptides), functionalized liposomes and nanoparticles (nanocrystals, light-sensitive and magnetic nanoparticles). Therefore, CPPs have attracted considerable attention not only for their application as vectors for drug delivery but also as agents for diagnostics and therapy (theranostics) in medicine [28-31].

Regarding their mechanistic of cell penetrability, although not conclusively elucidated, it has been shown that CPPs traverse hydrophobic membranes and enter into cells through distinct routes, relying on both membrane-disruptive and non-disruptive processes, this later comprising energy-dependent, receptor-mediated and receptor-independent endocytosis, as well as energy independent, direct translocation strategies. Hence, pathways for CPP entry into cells involve: (I) non-disruptive endocytic routes, such as clathrin-mediated endocytosis, caveolae-mediated uptake, clathrin/caveolae-independent endocytosis and micropinocytosis; (II) non-disruptive membrane, direct translocation by alternative routes, like inverted micelle formation and "carpet" model penetration; (III) direct translocation by membrane-disruptive routes, such as pore-formation (toroid and barrel-stave pores) and electroporation-like permeabilization. Moreover, based on experimental evidence with numerous known CPPs, more than a single pathway of membrane permeation and cellular internalization may be involved, depending on the CPP physicochemical features, effective concentrations (i.e., the peptide-to-cell ratio) and targeted cell types $[19,20,32]$. Although distinct pathways are involved in membrane translocation and internalization of several distinct CPPs investigated, the mode of membrane interaction, the efficacy of CPP-mediated cargo-dependent transport, subcellular compartmentalization and eventual adverse cytotoxic effects, depend not only on their own CPP structures but also on the position and nature of the molecular cargoes and the types of cell targets, as observed with CPPs that were conjugated with fluorescent dyes and polypeptides [32-36].

Table 1 presents examples of CPP archetypes, their sequences, origins and physicochemical and structural attributes. 
Table 1. Examples of cell-penetrating peptide (CPP) archetypes, origins, sequences, secondary structures and physicochemical classes.

\begin{tabular}{|c|c|c|c|}
\hline CPP & Origin & Sequence & $\begin{array}{l}\text { Physicochemical Class and } \\
\text { Secondary Structure }\end{array}$ \\
\hline \multicolumn{4}{|l|}{ Protein-derived } \\
\hline $\mathrm{TAT}^{48-60}$ & Protein of HIV-1 & GRKKRRQRRRPQ & cationic random coil $(\mathrm{rdc}) *$ \\
\hline Penetratin (Antp $\left.{ }^{43-68}\right)$ & $\begin{array}{c}\text { Antennapedia homeodomain of } \\
\text { D. melanogaster }\end{array}$ & RQIKIWFQNRRMKWKK & cationic $\beta$-strand $/ \mathrm{rdc}$ * \\
\hline VP22 & Herpes simplex virus type I & NAKTRRHERRRKLAIER & amphipathic $\alpha$-helix \\
\hline pVEC & Cadherin $615-632$ & IRKQAHAHSK & amphipathic $\beta$-strand/rdc * \\
\hline \multicolumn{4}{|l|}{ Chimeric } \\
\hline Transportan & Galanine/Mastoparan & GWTLNSAGYLLGKINLKALAALAKKIL & amphipathic $\alpha$-helix * \\
\hline Pep-1 & $\begin{array}{c}\text { HIV-reverse transcriptase/SV40 } \\
\text { T-antigen }\end{array}$ & KETWWETWWTEWSQPKKKRKV & amphipathic $\alpha$-helix * \\
\hline MPG & HIV-gp41/SV40 T-antigen & GALFLGFLGAAGSTMGAWSQPKKKRKV & amphipathic $\beta$-strand/rdc \\
\hline \multicolumn{4}{|l|}{ Synthetic } \\
\hline Polyarginines & Based on Tat peptide & Poly-arginine, $(\mathrm{R})_{\mathrm{n}} ; 6<n<12$ & cationic rdc* \\
\hline MAP & designed & KLALKLALKALKAALKLA & amphipathic $\alpha$-helix * \\
\hline KALA & designed & WEAKLAKALAKALAKHLAKALAKALKACEA & amphipathic $\alpha$-helix \\
\hline
\end{tabular}

Note: Examples are based on references $[17,19,20]$. The mechanisms of membrane translocation and cell entry of these archetypal CPPs are not definitively elucidated. However, distinct mechanisms are involved, such as direct translocation (non-endocytic pathway, like an inverted micelle, pore formation, carpet-like and membrane thinning) and endocytosis-mediated internalization (macropinocytosis, clathrin- and caveolin-dependent endocytosis, clathrin- and caveolin-independent endocytosis and receptor-mediated endocytosis. These CPPs can utilize more than a single route for cell entry $[19,20,30]$. "**, as structurally characterized in the presence of negatively charged dioleoylphosphatidylglycerol [26].

Interestingly, most structural and physicochemical features of CPPs can be observed in members of another class of bioactive peptides, termed antimicrobial peptides (AMPs), which are ubiquitously found in cells, tissues and biological fluids of organisms from diverse kingdoms, including venoms of poisonous animals [37]. Indeed, based on their structural characteristics, AMPs are membrane-active peptides that possess the ability to disrupt the plasma membrane integrity of their respective cellular targets as their principal mechanism of action, and penetrate target cells through pores [38,39]. The cell penetrability of AMPs appears to reinforce their antimicrobial efficacy owing to the interaction and interference with intracellular components, including macromolecules and organelles [40]. In this case, cellular uptake and permeability of AMPs can be associated with variable levels of cytotoxicity. However, the design and synthesis of AMPs can provide engineered peptides with tuned membrane translocation and cellular uptake capabilities, combined with lower or absent detrimental effects on membrane stability and cell viability, as exemplified by buforin II from the stomach tissue of the Asian toad Bufo bufo garagrizans and derivates [41] and other AMPs [42], including some presented in this article, in following sections.

To date, native venom peptides with cell-penetrating properties have been identified in a limited number of species of insects (bees and wasps), arachnids (spider and scorpions), fishes, amphibians and snakes (elapids and pit vipers). These CPPs have dual or multiple biological activities and are derived from the venoms or skin secretions, which are toxigenic, cytotoxic or antimicrobials. Thus, in this review, the origins, basic research and advances regarding these venom peptides and related sequences, as well as their original single, dual or multiple biological activities, including cell-penetrating properties, are presented and discussed. These venom CPPs include melittin from the honeybee, anoplin and mastoparans from wasps, latarcin and lycosin from spiders, chlorotoxin, maurocalcine and imperatoxin from scorpions, cardiotoxin, crotamine, crotalicidin and elapid cathelicidin-related antimicrobial peptides (CRAMPs) from snakes, pardaxin from fish skin and bombesin from frog skin, all presented in following sections. The importance of this theme and class of bioactive peptides relies on the fact that venom peptides and toxins, as well as related sequences, have evolved for millions of years of natural history and can be considered crucial improvements in peptide design that efficiently performs their functions. Thus, recombinant products, peptide chimeras and synthetic analogs can 
be engineered and prepared for biomedical applications, as well as potentially converted into biopharmaceuticals.

\section{Cell-Penetrating Peptides from Animal Venoms and Toxins}

An increasing number of studies have reported on the applicability of venom peptides in the diagnosis and prospective treatment of diseased processes that are dependent on selective and specific cell membrane interaction and/or receptor binding, translocation across the cell membrane (cell penetration), intracellular trafficking and subcellular localization to exert their effect. For instance, the antitumor activity of scorpion neurotoxins, which are venom peptides that particularly act on ion channels, has been established [43]. Furthermore, venom peptides that possess cell-penetrability properties and druggability have been identified from the venom of other arachnids and insects. The first two subsections outline well-documented examples of venom peptides from honeybees, wasps, spiders and scorpion with cell penetration features. The following subsections discuss venom peptides with cell penetration ability derived from fish, amphibians and snakes. These examples of CPPs characterized from animal venoms and toxins will illustrate their multifaceted biological activities and their potential and practical application in clinics and biomedicine. Tables $2-4$ summarize venom peptides and derivatives with cell-penetrating properties, their overall structures and mode of cell entry, as discussed in the text.

\subsection{CPPs from Insects}

2.1.1. Melittin

Melittin is the major peptide component of the European honeybee Apis mellifera venom, comprising up to $60 \%$ of the dried crude venom. This cationic peptide, with a primary sequence consisting of 26 amino acid residues (GIGAVLKVLTTGLPALISWIKRKRQQ$\mathrm{NH} 2$ ) segmented in a hydrophobic C-terminus followed by a hydrophilic N-terminus, adopts an amphipathic $\alpha$-helix topology that is typical of membrane-interacting and lytic peptides $[44,45]$. Owing to its structural conformation, melittin, at low concentrations, inserts into neutrally charged lipid bilayers and phospholipid membranes, such as the AMP indolicin-derivatives and the Arg-rich TaT CPP. After membrane insertion, melittin forms transmembrane pores at higher concentrations, as observed by direct visualization using in situ atomic force microscopy and dynamic computer simulation [46,47]. The direct physical and chemical membrane-disrupting and cytolytic effects endow melittin with broad-spectrum anti-infective and anticancer activities, thus presenting the concept of converting cytolytic venom-peptides into safe therapeutics $[44,45,48]$. Reportedly, fluorescent dye (AlexaFluor 430)-conjugated peptides with both the monomeric and dimeric forms of melittin can penetrate human gastric cancer (NUGC-3) cells and accumulate in the nuclear membrane, causing shrinkage of the nucleus and contributing to the cell death effect [49]. In addition to a variety of pharmaceutical formulations and derivatization, which have been conceived to improve the druggability of melittin and avoid side effects of hemolysis and nonspecific damage to healthy cells [48,50,51], melittin derivatives and short peptide analogs have also been designed with disruptive and non-disruptive cell membrane penetrability. For instance, a chimeric peptide was developed that fused the Tat11 CPP and CM18 hybrid (KWKLFKKIGAVLKVLTTG, residues 1-7 of cecropin-A and 2-12 of melittin), which combined plasma membrane translocation and endosomal escape and was successfully applied for the delivery of several types of cell-impermeant cargoes [52]. The cell-penetrating activity of the chimeric melittin peptide constructs has been investigated in terms of the directional target and selective death of tumor-associated M2-type macrophages. Hence, a chimeric peptide hybrid consisting of melittin fused via a GGGGS linker to the pro-apoptotic peptide d(KLAKLAK) ${ }_{2}$ (i.e., GIGAVLKVLTTGLPALISWIKRKRQQGGGGS-d[KLAKLAKKLAKLAK]) efficiently induced the selective mitochondrial-mediated apoptotic cell death of M2 macrophages in vitro and $\left(\mathrm{CD}^{206^{+}}\right)$M2-like tumor-associated macrophages in vivo, reducing tumor growth rates, tumor mass and angiogenesis [53]. In another interesting example, melittin- 
derived peptides were developed, with C-terminal sequences modified to include Arg and His residues for peptide-nucleotide interaction and $\mathrm{pH}$ sensing, resulting in the peptides p5RHH (VLTTGLPALISWIRRRHRRHC) and p5RWR (VLTTGLPALISWIKRKRQQRWRRRR). Notably, p5RHH arrested proliferation of immortalized and cancer cells, to inhibit metastasis in a cancer mouse xenograft model, as well as transfected cells and delivered siRNAs into the cytoplasm [54,55]. Truncated versions of melittin were reported to enhance the $\mathrm{pH}$-dependent endosomal escape of DNA-polymer vector complexes (polyplexes) and, therefore, the transfection efficiency [56]. As demonstrated in this study, the truncated melittin derivatives, consisting of residues 1 to 20 (MT20, GIGAVLKVLTTGLPALISWI and FL20, GIGAILKVLATGLPTLISWI) showed low hemolytic activity at neutral $\mathrm{pH}$ but were membranotlytic in the acidic milieu of endosomes. These melittin-derived peptides did not interfere with the formation and stability of branched polyethyleneimine DNA polyplexes and improved transfection and DNA delivery in immortalized and cancer cells. Moreover, melittin fragments have been shown to enhance the cellular uptake of macromolecules. In several eukaryotic cell lines, the N-terminal melittin fragment 1 to 14 (GIGAVLKVLTTGLP) demonstrated high efficiency in the internalization of fluorescent nanocrystals and large proteins [57].

\subsubsection{Anoplin}

Anoplin (GLLKRIKTLL-amide) is a short (10-residue), amphipathic, $\alpha$-helical antimicrobial peptide purified from the venom of the Japanese solitary wasp Anoplius samariensis [58]. The membrane interaction of anoplin was verified using lipid monolayers imaged using atomic force microscopy and X-ray spectromicroscopy [59]. Owing to its simple structure and a broad spectrum of biological and pharmacological activity, anoplin has attracted research interest in terms of chemical manipulation and structural modification, to modulate its activity and bioavailability, as recently reviewed [60]. Particularly, the $\mathrm{C}-\mathrm{N}$ terminal dimerization of anoplin not only showed superior stability and performance when compared with the parent peptide but also and importantly, enhanced inner membrane permeability and DNA binding ability [61]. These improved properties and performance of structurally modified anoplin have inspired the design of self-assembling anoplin derivatives for selective and sustained antibiosis [62], as well as conceived in situ tumor microenvironment-induced self-assembly of polymer-anoplin conjugates to attack solid tumors and analogous with other peptide-functionalized nanoconjugates [60,63].

\subsubsection{Mastoparan}

Mastoparan (INLKALAALAKKIL-amide) is a cationic tetradecapeptide with an amphipathic character derived from the venom of the Korean leather-jacket Vespula lewisii that corresponds to up to $50 \%$ of the crude venom and has demonstrated mast cell degranulation when injected [64]. A highly similar peptide (mastoparan-X, INWKGIAAMAKKLL-amide) was subsequently characterized from the venom of the Japanese hornet $\mathrm{V}$. xanthoptera [65]. Mastoparan and related-peptides have served as a versatile structural scaffold to design diverse CPPs, as exemplified by the mitoparan-serie and transportans [66-68]. Transportan (GWTLNSAGYLLGKINLKALAALAKKIL-amide) is a designed, 27-residue chimeric peptide that was constructed by joining the $\mathrm{N}$-terminal residues 1 to 12 of the neuropeptide galanin (GWTLNSAGYLLG) via a lysine residue $\left(\mathrm{Lys}^{13}\right)$ to the mastoparan 14-residue sequence [66]. Transportan 10 (AGYLLGKINLKALAALAKKIL-amide) is a deletion analog of transportan [67]. In aqueous solution, both mastoparan and transportan present a disordered structure, which is converted into a $\alpha$-helical structure upon interaction with micelles and binding to lipid membranes [69]. The mechanism of membrane interaction, binding and cell penetration is essentially the same for mastoparans and transportan, as quantitatively demonstrated with biomembrane models [70]. Transportan and transportan 10 are two of the most studied designed mastoparan-derived peptides that possess significant cell-penetrating properties. The 27-residue transportan, galanin-mastoparan chimera, was biotinylated at Lys ${ }^{13}$ and radiolabeled with $\mathrm{I}^{135}$ to assess its cellular uptake, intracellular 
distribution and localization. As detected with biotinyl-transportan and ${ }^{125}$ I-biotinyltransportan, the cell penetration of this peptide is highly efficient, energy- independent and occurs rapidly ( $<30 \mathrm{~min}$ ). Transportan traverses the plasma membrane and is also endocytosed by several lines of eukaryotic cells, entering the cytoplasm and accumulating in the nucleus and subnuclear structures. Moreover, Lys $^{13}$ serves as a connector for attachment molecular cargoes by covalent conjugation [66]. It was shown that increasing the charge and amphipathicity of transportan 10 but preserving the helical structure of the mastoparan stretch, like in transportan 10-5 (AGYLLGKINLKKLAKL(Aib)KKIL-amide), resulted in analogs with improved penetrability and preference for cancer cells over healthy cells [71]. Transportan and transportan-derived CPPs have been investigated for various prospective biomedical applications. For instance, PepFecs, stearyl-derivatives of TP10, are low cytotoxic and immunogenic CPPs endowed with endosomal escape properties and the ability to deliver nucleic acids both in vitro and in vivo; hence, these analogs not only improved the efficiency of transport and delivery of therapeutic agents but also decreased the risks of adverse effects [72]. A chimeric transportan, namely Transportan 9dR (GWTLNSAGYLLGKINLKALAALAKKILdRdRdRdRdRdRdRdRdR, where $\mathrm{dR}=\mathrm{D}$-arginine), was devised and used to form a complex and deliver siRNAs that target a gene segment of influenza virus H1N1 into epithelial cells of the respiratory tract, with efficient inhibition of viral replication achieved both in vitro and in vivo [73]. Microemulsions containing paclitaxel loaded with transportan showed improved penetrability and enhanced delivery, with superior efficacy of the antitumor drug against cutaneous tumor cells in culture and in skin cancer models [74]. In addition to these examples of cellular uptake and cargo delivery, transportan 10 and its analogs display significant antimicrobial activity against multi-drug resistant and clinically relevant bacteria, mediating their effects by means of membrane perturbation, ligation to lipopolysaccharides and binding to intracellular DNA $[75,76]$. Notably, vancomycin covalently linked to transportan 10 at is C-terminal, as in the conjugates AGYLLGK7(C(O)-Tra(1,4)-PEG4-C(O)-Van)INLKALAALAKKIL-amide and AGYLLGKINLKALAALAKKIL-Ala(Tra(1,4)-PEG4-C(O)-Van)-amide (where PEG4 is the linker group and Van is vancomycin), substantially increased the antibacterial activity of the conjugates against intracellular or extracellular compartmentalized multi-drug resistant bacteria in vitro. Moreover, transportan-vancomycin conjugates, including [Lys7(PEG4Van)]TP10 and its fluorescent analog, translocated across the blood-brain barrier and accumulated in the cerebral tissue in an in vivo mouse model [77].

Mitoparan (INLKKLAKLAbiKKIL-amide), the $\left[\mathrm{Lys}^{5,8}, \mathrm{Aib}^{10}\right]$ mastoparan, was essentially designed by substituting Ala residues 5,8 and 10 of mastoparan with Lys ${ }^{5,8}$ and $\mathrm{Aib}^{10}$ ( $\alpha$-aminoisobutyric acid), resulting in analogs with lower cytotoxicity and better pharmacodynamic and intracellular target selectivity [68]. Mitoparan is a more potent secretagogue and cytotoxic agent than mastoparan, able to efficiently translocate across the plasma membrane of mammalian cells and localize to the mitochondria, where it can trigger apoptosis-mediated cell death [78]. Enantiomer analogs of mastoparan and mitoparan, such as the inverso (all D-amino acid residues), retro (reverse sequence) and retro-inverso, were synthesized to investigate the relationship between structure and activity, that is, cellular penetrability, mast cell degranulation ability and cytotoxicity [79]. Interestingly, all D-isomers of mastoparan and mitoparan preserved their intrinsic biological activities, while all D-mastoparan showed better translocation efficacy (cell penetrability), exceeding that of mitoparan, with reduced cytotoxicity and resistance to proteases. Reportedly, mastoparan and mitoparan cause mitochondrial depolarization and activation of the caspase cascade and kill cancer cells. Furthermore, an analog of mitoparan [Z-Gly-RGD(DPhe)-mitP] that consists of Z-glycine, the integrin-specific motif RGD and a D isomer of phenylalanine was developed to treat psoriasis, as well as to compartmentalize into the mitochondria and modulate its activity in transformed aneuploid immortal keratinocyte (HaCaT) cells from adult human skin [80]. 
Table 2. Examples of peptides from insect (honey bee and wasp) venom and derivatives with cell penetrating property.

\begin{tabular}{|c|c|c|c|c|c|c|}
\hline Peptide & Sequence $^{\mathrm{a}}$ & Size & $\begin{array}{l}\text { Major Structural } \\
\text { Features }^{b}\end{array}$ & $\begin{array}{c}\text { Mechanism(s) of } \\
\text { Cell } \\
\text { Penetration }\end{array}$ & Cargo Delivery $^{\mathrm{d}}$ & Ref. \\
\hline \multicolumn{7}{|l|}{ Honey bee } \\
\hline Mellitin (MEL) & GIGAVLKVLTTGLPALISWIKRKRQQ-NH2 & 26 & $\begin{array}{l}\text { Amphipathic } \\
\alpha \text {-helix }\end{array}$ & DT, PF & FD & [49] \\
\hline \multirow{2}{*}{$\begin{array}{c}\text { Tat/CM18 hybrid } \\
\text { MEL- } \\
\text { d(KLAKLAK) }{ }_{2}\end{array}$} & \multirow[b]{2}{*}{$\begin{array}{l}\text { GIGAVLKVLTTGLPALISWIKRKRQQGGGGS- } \\
\text { d[KLAKLAKKLAKLAK] }\end{array}$} & \multirow{2}{*}{45} & Chimera & \multirow{2}{*}{$\begin{array}{c}\text { DT, MD, ND } \\
\text { DT (?) }\end{array}$} & $\mathrm{CI}$ & [52] \\
\hline & & & Chimera & & $\mathrm{AP}$ & {$[53]$} \\
\hline p5 $\mathrm{RHH}$ & VLTTGLPALISWIRRRHRRHC & 21 & $\begin{array}{l}\text { C-terminal } \\
\text { fragment }\end{array}$ & Endocytosis (?) & DNA polyplexes & {$[54,55]$} \\
\hline p5RWR & VLTTGLPALISWIKRKRQQRWRRRR & 25 & $\begin{array}{l}\text { C-terminal } \\
\text { fragment }\end{array}$ & Endocytosis (?) & DNA polyplexes & {$[54,55]$} \\
\hline $\begin{array}{l}\text { MT20 } \\
\text { FL20 }\end{array}$ & $\begin{array}{l}\text { GIGAVLKVLTTGLPALISWI } \\
\text { GIGAILKVLATGLPTLISWI }\end{array}$ & $\begin{array}{l}20 \\
20\end{array}$ & $\begin{array}{l}\text { Hydrophobic helix } \\
\text { Hydrophobic helix }\end{array}$ & $\begin{array}{l}\text { DT, MD } \\
\text { DT, MD }\end{array}$ & $\begin{array}{l}\text { DNA polyplexes } \\
\text { DNA polyplexes }\end{array}$ & {$[56]$} \\
\hline Melittin [1-14] & GIGAVLKVLTTGLP & 14 & $\begin{array}{l}\text { N-terminal } \\
\text { fragment }\end{array}$ & DT & $\mathrm{NC}, \mathrm{LP}$ & {$[57]$} \\
\hline Wasp & & & & & & \\
\hline Anoplin & GLLKRIKTLL-NH ${ }_{2}$ & 10 & $\begin{array}{l}\text { Amphipathic } \\
\alpha \text {-helix }\end{array}$ & DT, PF & FD & {$[60]$} \\
\hline Anoplin dimer & $(\text { GLLKRIKTLL-NH })_{2}$ & 20 & $\mathrm{C}-\mathrm{N}$ terminal dimer & DT, PF & - & {$[61]$} \\
\hline Mastoparan & INLKALAALAKKIL-NH 2 & 14 & $\begin{array}{l}\text { Amphipathic } \\
\alpha \text {-helix }\end{array}$ & DT, PF & - & {$[64]$} \\
\hline Mastoparan-X & INWKGIAAMAKKLL-NH ${ }_{2}$ & 14 & $\begin{array}{l}\text { Amphipathic } \\
\alpha \text {-helix }\end{array}$ & DT, PF & - & {$[65]$} \\
\hline $\begin{array}{l}\text { Transportan } \\
\text { TP10 } \\
\text { TP10-5 } \\
\text { Transportan 9dR }\end{array}$ & $\begin{array}{l}\text { GWTLNSAGYLLGKINLKALAALAKKIL-NH } \\
\text { AGYLLGKINLKALAALAKKIL-NH } \\
\text { AGYLLGKINLKKLAKL(Aib)KKIL-NH } \\
\text { GWTLNSAGYLLGKINLKALAALAKKIL(dR)9 }\end{array}$ & $\begin{array}{l}27 \\
21 \\
21 \\
36\end{array}$ & $\begin{array}{l}\text { Chimera } \\
\text { Shorter transportan } \\
\text { Helical stabilized } \\
\text { Chimera }\end{array}$ & $\begin{array}{l}\text { multiple } \\
\text { multiple } \\
\text { DT } \\
\text { Endocytosis (?) }\end{array}$ & $\begin{array}{l}\text { CI } \\
\text { CI } \\
\text { FD } \\
\text { siRNA }\end{array}$ & $\begin{array}{c}{[66]} \\
{[70,77]} \\
{[71]} \\
{[73]}\end{array}$ \\
\hline Mitoparan & INLKKLAKL(Aib)KKIL-NH $\mathrm{N}_{2}$ & 14 & $\begin{array}{l}\text { Mastoparan } \\
\text { analogue }\end{array}$ & DT & $\mathrm{FD}, \mathrm{AP}$ & [78-80] \\
\hline
\end{tabular}

Notes: ${ }^{a}-\mathrm{NH} 2$, amidated peptide; anoplin $\mathrm{C}-\mathrm{N}$ terminal dimer, as prepared by intermolecular triazole bridge; Aib, $\alpha$-aminoisobutyric acid; ${ }^{b}$ Particular structural characteristics of native, designed or analogous peptides; $\mathrm{C}-\mathrm{N}$ terminal dimer, intermolecular dimerization involving the carboxyl-terminus of one peptide and the amino-terminus of the other; ${ }^{\mathrm{c}} \mathrm{DT}$, direct translocation; $\mathrm{PF}$, pore forming; $\mathrm{MD}$, membrane-disruptive cell uptake; NR, non-disruptive penetration; RM, receptor-mediated endocytosis; HI, hydrophobic insertion; multiple more than a single mechanism of cell entry, that can involve direct translocation and endocytosis; ${ }^{\mathrm{d}} \mathrm{FD}$, fluorescent dyes; $\mathrm{CI}$, diverse types of cell impermeant cargoes; AP, apoptotic peptides; NC, nanocrystals; LP, large proteins; RD, radionuclides; EZ, enzymes; IR, infrared; "-," not applicable.

\subsection{CPPs from Arachnids}

\subsubsection{Latarcin-1}

The latarcins comprise a group of membrane-interacting peptides from spider venom that possess cytolytic and antimicrobial properties, with potential cell-penetrating activity. Latarcins are 25- to 30-residue peptides, rich in Lys and Arg, derived from the venom of the spider Lachesana tarabaevi [81]. Short latarcin 1-derived decapeptide (KWRRKLKKLR) was designed using an algorithm, labeled using fluorescein isothiocyanate (FITC) and shown to be cytotoxic to human cervix cancer (HeLa) cells, with low levels of cellular uptake. However, prolongation of its C-terminus by chemical conjugation with the nuclear localization sequence (NLS) from Simian Virus T40 antigen (PKKKRKV) resulted in a chimeric latarcin 1-derived peptide (KWRRKLKKLRPKKKRKV), which displayed improved cell translocation efficiency and lower cytotoxicity, as observed by the accumulation of the fluorescent analog in lysosomes after endocytosis. Moreover, the chimeric latarcin-derived peptide was efficiently transported and delivered into the cytoplasm of adherent cells, along with a large reporter enzyme ( $\beta$-galactosidase) in its active form [82]. In this case, although cell-penetration was enhanced by peptide engineering, i.e., by conjugation of an NLS, the intrinsic biological activity of the latarcin-derived peptide appeared to be essential for use as bivalent AMP/CPP. Indeed, this dual activity of latarcin 1-derived peptides was demonstrated with FITC-labeled analogs in spores and hyphae of the plant pathogenic fungus Fusarium solani, in which the NLS conjugated at the peptide C-terminal contributed to enhancing the internalization of the chimeric peptide, with selective and variable level of antifungal activity [83].

\subsubsection{Lycosin-I}

Lycosin-I is a linear, cationic, 24-residue peptide (RKGWFKAMKSIAKFIAKEKLKEHL) from the venom of the spider Lycosa singorensis that forms an amphiphilic $\alpha$-helix upon interaction with lipid membranes. Several studies have demonstrated the antibacterial and 
antitumor activities of lycosin-I, along with its ability to selectively enter into the cytoplasm of tumor cells and activate antiproliferative and cell death signaling [84-86]. Tan and colleagues [87] quantitatively demonstrated, by single-molecule fluorescence imaging with internal reflection fluorescence microscopy, the time-dependent aggregation and diffusion of rhodamine B-labeled lycosin-I on a neutral lipid membrane model as part of its mechanism of cell penetration, as well as anticancer activity and selectivity. Owing to the cell penetration and antitumor activities, lycosin-I was used to functionalize gold nanoparticles, to target and penetrate tumors, as confirmed in vitro and in vivo with different tumor cell lines and a mouse xenograft tumor model, respectively. Moreover, as this spider venom peptide preferentially accumulated in tumor cells and tissues, lycosin-I functionalized gold nanoparticles were efficiently used to kill cancer cells by the photothermal conversion effect under near-infrared irradiation [88]. Notably, the substitution of all Lys residues in lycosin-I peptide with Arg resulted in the R-lycosin-I (Ac-RGWFRAMRSIARFIARERLREHL-amide), which displayed improved anticancer activity and cellular penetrability against solid tumor cells, as assessed by employing unlabeled peptides and fluorescent-labeled analogs, prepared by conjugation with cyanine 5 (Cy5-lycosin-I) and FITC (FITC-R-lycosin-I) [89].

\subsubsection{Chlorotoxin}

Chlorotoxin ("CTX," MCMPCFTTDHQMARKCDDCCGGKGRGKCYGPQCLCR) is a 36-residue neurotoxin with the typical inhibitor cystine knott (ICK)/knottin fold, derived from the venom of the Israeli yellow scorpion Leiurus quinquestriatus [90]. CTX is one of the few known examples of neurotoxic peptides that exert its effect on small-conductance epithelial chloride ion channels but it also binds with high affinity to the matrix metalloproteinase 2 (MMP2) receptor on the target glioma cell membrane in neuroblastoma, avoiding healthy glial cells [91]. Owing to the high specificity and selectivity for glioma cells that overexpress MMP2, the synthetic version of CTX (designated, TM-601) has been used in clinical imaging and therapy of malignant glioma tumors, as exemplified by $\mathrm{I}^{131}$-iodination of the Tyr residue of the peptide, which produces $\mathrm{I}^{131}$-TM-601 used in radiodiagnostics and radiotherapy [92]. The multimodality of CTX in terms of its application in diagnosis and prospective therapy, as bioconjugates and theranostic agents to image and treat glioma was recently reviewed [93]. Accordingly, bioconjugates of CTXs include, for instance, crystal and magnetic nanoparticles, polymer-blend dots, in addition to the radiolabeled $\mathrm{I}^{131}$-TM-601. Notably, the compact and tight structure endows CTX with the ability to cross the blood-brain barrier and accumulate in glioma tumors. The routes of entry, intracellular trafficking and subcellular localization of CTX (TM-601) in glioma cells was compared with healthy cells using unlabeled and fluorescently labeled (Alexa Fluor 488) TM-601 [94]. Accordingly, cellular uptake of TM601 in U373 glioma cells was a rapid concentrationand time-dependent process, which was affected by chlorpromazine, a pharmacological inhibitor of clathrin-mediated endocytosis, involved in the transport of coated pits. Interestingly, as in the case of lycosin-I from spider venom, the replacement of Lys with Arg in the CTX sequence, as observed with the synthetic analogs [K15R/K23R]CTX and [K15R/K23R/Y29W], enhanced its cellular uptake, as demonstrated in human cervical carcinoma (HeLa) cells with fluorescent derivatives [95].

\subsubsection{Maurocalcine}

Maurocalcine ("MCa," GDCLPHLKLCKENKDCCSKKCKRRGTNIEKRCR) is a 33amino acid long, cationic peptide isolated from the venom of the Tunisian scorpion Scorpio maurus palmatus. In solution, MCa folds to adopt the canonical ICK/knottin motif, in a three-stand arrangement $(\beta \beta \beta)$ constrained by three disulfide bonds. The main biological activity of $\mathrm{MCa}$ is to activate the ryanodine receptor (RyR) to induce, within seconds, $\mathrm{Ca}^{2+}$ release from the sarcoplasmic reticulum (SR) of myotubes in the skeletal muscle $[96,97]$. To exert its pharmacological action on the RyR channel and release calcium ions from intracellular stores, MCa translocates across the plasma membrane and accumulates in the cytoplasm and the nucleus of cells [98]. Furthermore, it was observed that the fast kinetic 
cellular uptake of non-covalently linked MCa complexes with streptavidin-cyanine 3 (Су3) or cyanine 5 (Cy5) is independent of metabolic energy or endocytosis but needs to interact with negatively charged lipids (e.g., gangliosides and/or phosphatidylserine) on membrane surface domains for translocation, as well as with the negative potential of cells [99]. Similar to some CPPs, in addition to transporting large complexed cargoes such as streptavidin, MCa delivered other kinds of molecules inside cells, including the chemotherapeutic drug doxorubicin into human breast cancer cells $[100,101]$. This disulfide-rich peptide with relatively large size, at first glance, presents apparent disadvantages, including the need for conversion into carrier vectors for delivery of cell-impermeant compounds and nanoparticles; accordingly, disulfide-less and short derivatives of $\mathrm{MCa}$, including a nontoxic all D-amino acid isomer, were prepared and investigated [102-104]. For instance, all D-isomers and disulfide-less MCa lacked pharmacological activity but preserved cell penetrability, while unstructured short analogs revealed variable but efficient levels of cellular penetrability and uptake $[103,105]$. Despite these shortcomings of structural downsizing and necessity to circumvent the in vitro folding of synthetic full-size $\mathrm{MCa}$, the disulfide bond-cross-linked ${ }^{125} \mathrm{I}$-Tyr-MCa (an MCa analog with the three native disulfide bridges but an extra $\mathrm{N}$-terminal Tyr residue for $\mathrm{I}^{125}$-radiolabeling) was still the most stable version detected in the bloodstream of intravenously injected mice when compared with the linear version (Lin- ${ }^{125} \mathrm{I}-\mathrm{Ty}-\mathrm{MCa}$ ) that degrades rapidly. Moreover, after biodistribution, the ${ }^{125} \mathrm{I}-$ Tyr-MCa concentrated in diverse tissues, mainly in the thyroid, except for the brain, owing to its inability to cross the blood-brain barrier [106]. Maurocalcine covalently conjugated with platinum and gold nanoparticles and functionalized with MCa-derived peptides have been prepared for biopharmaceutical applications $[107,108]$.

\subsubsection{Imperatoxin}

Imperatoxin A ("IpTxa," GDCLPHLKRCKADNDCCGKKCKRRGTNAEKRCR) is a 33-residue in length, cationic, ICK-like peptide from the venom of the African scorpion Pandinus imperator, which reversibly activates the RyR to release calcium ions from the SR into the cytoplasm of muscle cells. Owing to the sequence identity and structural similarity with maurocalcin, Gurrola and colleagues prepared fluorescent derivatives of IpTxa, with Alexa Fluor 546 covalently conjugated to the thiolated peptide and confirmed that this scorpion venom toxin traversed the cell membrane and internalized into mouse ventricular cardiomyocytes in vitro to exert its intracellular effect on the RYR [109].

\subsubsection{Hadrucalcin}

Hadrucalcin ("HdCa," SEKDCIKHLQRCRENKDCCSKKCSRRGTNPEKRCR), a basic 35-residue peptide purified from the venom of the Mexican scorpion Hadrurus gertschi, like maurocalcine and imperatoxin, is an activator of RYRs [110]. Like its congeners, $\mathrm{HdCa}$ traversed the plasma membrane of cardiac ventricular myocytes and activated the skeletal RYR (RYR1) of the SR, rapidly releasing intracellular calcium for muscle contraction. Although speculative, the authors who first characterized HdCa [110] believed that the pentapeptide sequence KKCXR, present in all members of the calcin family, might be the segment responsible for cell penetration of this peptide, despite the uniform distribution of positive residues in the peptide structure and overall low amphiphaticity of HdCa. Nevertheless, from the HdCa, a short size cell-penetrating peptide ("HadUF $1-11$, H11", SEKDAbu $\mathrm{IKHLQR}_{11}-\mathrm{C}$ ) was designed and used to functionalize quantum dot (QD) nanoparticles in combination with PEG5-CaRuby [111]. This biofunctionalized QDCaRuby-H11 efficiently penetrated Baby hamster kidney (BHK21) cells in culture and served as a nanobiosensor to detect transient fluctuations in intracellular calcium levels in BHK21 and HEK293 cells expressing $\mathrm{Ca}^{2+}$-permeable $\mathrm{N}$-methyl-D-aspartate receptors (NMDARs), by employing through fluorescence resonance energy transfer (FRET) measurements and total internal reflection fluorescence (TIRF) imaging. 


\subsubsection{Wasabi Receptor Toxin}

From the venom of the Australian Black Rock scorpion Urodacus manicatus, Lin King et al. [112] characterized a unique venom peptide (Wasabi receptor toxin, WaTx), with a mechanism of action that resembles that of plant irritants (piquants from allium and mustard plants) and acts via the chemosensitive TRPA1 ion channel present in afferent sensory neurons. Using a combination of electrophysiology, intracellular calcium imaging and FRET, with Alexa Fluor 488 labeled-WaTx and AlexaFluor568-IgG-loaded liposomes, it was observed that WaTx modulated intracellularly the TRPA1 channel activity after translocation across the lipid membrane. WaTx (ASPQQAKYCYEQCNVNKVPFDQCYQMCSPLERS), with 33 residues, is a K-KTx scorpion toxin-like peptide that adopts a stable helical hairpin fold maintained by two disulfide bonds (C1-C4-and C2-C3) and the basic patch at the open end of the cysteine-stabilized helical hairpin was postulated as the cell-penetrating motif of WaTx.

Table 3 summarizes the peptides and derivatives from arachnid (spider and scorpion) venoms with cell-penetrating and cargo delivery capacity.

Table 3. Examples of peptides and derivatives from arachnid venoms with cell-penetrating and cargo delivery capacity.

\begin{tabular}{|c|c|c|c|c|c|c|}
\hline Peptide & Sequence & Size & $\begin{array}{l}\text { Major Structural } \\
\text { Features }\end{array}$ & $\begin{array}{c}\text { Mechanism(s) } \\
\text { of Cell } \\
\text { Penetration }\end{array}$ & $\begin{array}{l}\text { Cargo } \\
\text { Delivery }\end{array}$ & Ref. \\
\hline Spider & & & & & & \\
\hline Latarcin-1 (Ltc1) & SMWSGMWRRKLKKLRNALKKKLKGE & 25 & cationic $\alpha$-helix & DT, PF & FD & [81] \\
\hline Ltc1-decapeptide (LDP) & KWRRKLKKLR & 10 & Designed & DT & FD & [82] \\
\hline LDP-NLS & KWRRKLKKLRPKKKRKV & 17 & Chimera & ED & FD, EZ & [83] \\
\hline Lycosin-I & RKGWFKAMKSIAKFIAKEKLKEHL & 24 & $\begin{array}{l}\text { Amphipathic } \\
\alpha \text {-helix }\end{array}$ & DT, ND & $\mathrm{FD}, \mathrm{NP}$ & {$[87,88]$} \\
\hline R-lycosin-I & Ac-RGWFRAMRSIARFIARERLREHL-amide & 24 & $\begin{array}{l}\text { Lys } \rightarrow \text { Arg } \\
\text { analogue }\end{array}$ & ED & FD & [89] \\
\hline \multicolumn{7}{|l|}{ Scorpion } \\
\hline Chlorotoxin (CTX) & MCMPCFTTDHQMARKCDDCCGGKGRGKCYGPQCLCR & 36 & ICKfold/knottin & ED & FD, RD & [91-93] \\
\hline [K15R/K23R]CTX́ & MCMPCFTTDHQ̄MARRCDDCCGGRGRGKCYGPQCLCR & 36 & Mutant analogue & ED & FD & [95] \\
\hline$[\mathrm{K} 15 \mathrm{R} / \mathrm{K} 23 \mathrm{R} / \mathrm{Y} 29 \mathrm{~W}] \mathrm{CTX}$ & MCMPCFTTDHQ̄MARRCDDCCGGRGRGKCWGPQ̄CLCR & 36 & Mutant analogue & ED & FD & [95] \\
\hline Maurocalcine (MCa) & GDCLPHLKLCKENKDCCSKKCKRRGTNIEKRCR & 33 & ICK fold/knottin & DT, ND & $\mathrm{CI}, \mathrm{NP}$ & [99-101] \\
\hline MCaUF1-9-C & GDAbuLPHLKLC & 10 & Truncated, unfold & DT & FD & [105] \\
\hline Imperatoxin A (IpTxa) & GDCLPHLKRCKADNDCCGKKCKRRGTNAEKRCR & 33 & ICK fold/knottin & $\mathrm{n}$ & FD & [109] \\
\hline Hadrucalcin (HdCa) & SEKDCIKHLQRCRENKDCCSKKCSRRGTNPEKRCR & 35 & ICK fold/ knottin & DT, ND & - & [110] \\
\hline HadUF $_{1-11}(\mathrm{H} 11)$ & SEKDAbuIKHLQR-C & 12 & $\begin{array}{c}\text { N-terminal } \\
\text { fragment }\end{array}$ & DT, ND, ED (?) & NP & [111] \\
\hline WaTx & ASPQQAKYCYEQCNVNKVPFDQCYQMCSPLERS & 33 & CS-helical hairpin & DT, ND & FD & [112] \\
\hline
\end{tabular}

Notes: Ac, acetylated; $-\mathrm{NH}_{2}$, amidated; Abu, Lys $\rightarrow$ Arg replacement; C-S, cysteine stabilized $\alpha$-helix; DT, direct translocation; PF, pore forming; $\mathrm{ED}$, endocytosis;; ND, non-disruptive penetration; RM, receptor-mediated endocytosis; HI, hydrophobic insertion; multiple, more than a single mechanism of cell entry, that can involve direct translocation and endocytosis; " $n$ ", not informed; FD, fluorescent dyes; EZ, enzymes; NP, nanoparticles; RD, radionuclides; CI, diverse types of cell impermeant cargoes; "_", not applicable.

\subsection{CPPs from Fish \\ Pardaxins}

Pardaxins (P1 to P5) comprise a group of potent pore-forming, ichthyotoxic peptides that are secreted into seawater by the Mose sole fishes of the genus Pardachirus (P. marmoratus and P. pavoninus), all possessing similar structures composed of a single-chain acidic peptide of 33-residue, with an $\mathrm{N}$-terminal hydrophobic $\alpha$-helix connected via a dipeptide (SerPro) to a C-terminal amphiphilic $\alpha$-helix (helix-hinge-helix) [113,114]. Natural or synthetic peptides are inserted into phospholipid-containing membranes, forming pores and inducing the cytolysis of both healthy and tumor cells, as well as the death of Gram-negative and Gram-positive bacteria $[115,116]$. Amino acid substitution, as seen in the second helix of pardaxins P4 and P5 and acylation of N-terminal Gly of P5, reportedly modulate membrane insertion and cytotoxicity $[116,117]$. In this respect, the conjugated cyanine 3 acylated pardaxin (Cy3-pardaxin 5 ) loses its cytotoxicity but retains its ability for membrane insertion, importantly, resulting in internalization and accumulation in the nucleus of neuroblastoma (NG108-15) and bovine chromaffin cells [117]. 


\subsection{CPPs from Amphibian}

Bombesin

Bombesin (EQRLGNQWAVGHLM- $\mathrm{NH}_{2}$ ) is a neuroactive tetradecapeptide originally isolated from the skin of the European fire-bellied toad Bombina bombina by Erspamer and collaborators (1971) [118]. Bombesin is included in this review as, like venoms, frog skin secretions usually contain defensive neuroactive and cytolytic peptides (e.g., opioid peptides, triptopyllins and AMPs) that act in concert to intoxicate the endocrine and nervous system of predators; hence, they are potentially toxic to vertebrates and mammalian organisms [119]. Bombesin adopts an environmental-dependent topology that supports a hairpin turn at the N-terminus and helical structures at the C-terminus [120]. Reportedly, bombesin binds with high affinity to the gastrin-releasing peptide receptor (GRPR) of target cells and the short C-terminal fragments (residues 7 to 14, WAVGHLMH-amide), sharing identity with gastrin-releasing peptide (GRP), was found to be crucial and sufficient for receptor binding, as well as the biological activity of bombesin-like peptides [118]. The bombesin/GRP receptor subtype 2 is known to be overexpressed in diverse cancer types, allowing the application of radiolabeled bombesin-like peptide analogs as tracers for the detection and/or treatment of G-protein-coupled receptor (GPCR)-positive tumors [121,122]. For instance, short bombesin-like peptide analogs with natural and nonnatural amino acids have been synthesized and labeled with radionuclides $(99 \mathrm{mTc}, 111 \mathrm{In}$, $90 \mathrm{Y}, 64 \mathrm{Cu}, 177 \mathrm{Lu}, 68 \mathrm{Ga}$ or $18 \mathrm{~F}$ ) and evaluated in vivo and in vitro in animal models and humans to detect GPCR-overexpressing tumors [121,123]. A formulation of multivalent Tat $^{49-57}$-Lys3-bombesin ${ }^{1-14}$ chimera-functionalized 99mTc/177Lu-labeled gold nanoparticles (99mTc/177Lu-AuNP-Tat-BN) was prepared and internalized efficiently into the nucleus of prostate cancer (PC3) cells, relocating to the membrane after uptake of cytoplasmic accumulated bombesin, allowing the application of plasmonic photothermal therapy and targeted radiotherapy in prostate tumors [124].

\subsection{CPPs from Snakes}

\subsubsection{Crotamine}

Crotamine, the first snake venom peptide known to selectively penetrate eukaryotic cells, is a 42-residue cationic peptide purified from the venom of certain populations of the South American rattlesnake Crotalus durissus terrificus and other subspecies of C. durissus [125-127]. Pharmacologically, at the molecular level, crotamine is essentially a neurotoxin that exerts its effect at nanomolar concentrations on voltage-dependent $\mathrm{Na}^{+}$and $\mathrm{K}^{+}$ion channels of different types of muscle cells $[128,129]$. At higher toxic concentrations, it causes myonecrosis owing to a massive influx of sodium ions into the skeletal muscle cells of injected mice and is referred to as small basic myotoxin [130]. Structurally, crotamine (YKQCHKKGGHCFPKEKICLPPSSDFGKMDCRWRWKCCKKGSG) is constrained by three disulfide bridges that result in an $\alpha \beta \beta \beta$-fold, highly similar to that adopted by the human antimicrobial peptide $\beta$-defensin 2 and a restricted number of known toxins, despite differences in their primary sequences [131]. The $\beta$-defensin fold is a structural variant that is derived from a core motif generally present in peptides that are membrane-interacting and host defense effectors [132]. The high content of basic amino acid residues (nine lysines and two arginines) imparts crotamine a net positive charge and high cationicity, at physiological $\mathrm{pH}$, demonstrating important physicochemical features of its membrane interaction and translocation. Indeed, the membrane-modifying properties of crotamine were studied with monolayer and planar lipid bilayer of phospholipids, as well as with ex vivo basement membranes of the chicken retina, thus confirming crotamine oligomerization, membrane insertion, pore formation and lipid membrane-fusogenic properties [133,134].

The cell penetration property of crotamine, in addition to its antiproliferative activity and other functionalities, has been reviewed in several articles recently published [135], as well as in the last decade [136-138]. The penetrability of crotamine was observed with fluorescent cyanine 3-labeled native peptide and diverse cell types in culture, including mouse blastocysts and embryonic stem cells [139]. Cyanine 3-conjugated crotamine, at low 
micromolar non-toxic concentrations, selectively and rapidly penetrated (within minutes) actively proliferating cells, particularly those between the S/G2 and G2/M phases of the cell cycle; intracellularly, this conjugate bound to subnuclear components such as centrioles and chromosomes. The selective cellular uptake of crotamine was shown to depend on the endocytic route after its initial interaction with negatively charged heparan sulfate proteoglycans on the plasma membrane of target cells [140]. Moreover, crotamine binds to nucleic acids and forms stable peptide-DNA complexes $[140,141]$ intracellularly and in culture; accordingly, the intrinsic property of crotamine involves the unique functionality of a peptide vector to induce gene transduction of dividing cells. Reportedly, crotamine selectively interacts with and internalizes actively dividing proliferative cells, including cancer cells of epithelial origin in culture such as murine melanoma (B16-F10), human melanoma (SK-Mel-28) and human pancreatic carcinoma (Mia PaCa-2) cells, and its penetrability, tumor homing after biodistribution and anticancer activity, demonstrated in vivo using a murine model with engrafted subcutaneous melanoma [142]. The cell-penetrating efficacy of crotamine, associated with its anticancer activity, has been revealed in several in vitro and in vivo studies, with the subcellular and molecular details of its mode of action ascertained $[143,144]$.

Downsizing of crotamine produced short peptides such as CyLoP derivatives and nucleolar targeting peptides (NrTPs), with variable efficacy allowing translocation into the plasma membrane and localization to different cell compartments. CyLoPs (cytosollocalizing peptides) such as CyLoP-1 (CRWRWKCCKK) were designed based on the two encrypted nuclear localization signals predicted from the crotamine primary sequence: residues 2 to 28 (KQCHKKGGHCFPKEKIC) and 27 to 39 (KMDCRWRWKCCKK) [145]. CyLoPs explicitly accumulate in the cytosol, endosome and nuclear perimeter of distinct cells investigated. In contrast, the NrTPs mimic most crotamine features, such as rapid cellular uptake, homing to the nucleus and binding to mitotic chromosomes, while improving other features, such as a reduction in the peptide size and accumulation in the nucleolus. For instance, NrTP-1 (YKQCHKKGGKKGSG), a prototype of NrTP-serie, was designed based on the secondary structure of crotamine instead of the primary sequence, by splicing the spatially close Gly ${ }^{9}$ and $\mathrm{Lys}^{38}$. The flexible Ahx connector was included in one of the analogs, namely, NrTP-2 (YKQCHKKGG-Ahx-KKGSG), which was later proved to be dispensable for cellular penetrability of this crotamine derivative [146]. As demonstrated by specific pharmacological inhibitors of cell internalization pathways, NrTP-1 selectively and efficiently penetrated human pancreatic (BxPC-3) and human ductal mammary gland (BT-474) carcinoma cells, predominantly via clathrin-dependent endocytosis, although other entry portals were also employed [147]. The NrTP-1 prototype was further modified to produce analogs and investigate their structure-activity relationships. Overall, in a series of sequential studies, replacing the cysteine residue at position 4 in NrTP-1 for a serine resulted in an analog, namely NrTP-6 (YKQSHKKGGKKGSG), with a significantly improved performance in terms of its interaction with biomembranes, penetrability, cargo transportation of large macromolecules, concentration-independent internalization kinetics and negligible cytotoxicity to healthy cells [148-151]. The NrTP-6 analog, in which the near-infrared dye DY676 was coupled to an extra N-terminal cysteine residue in NrTP-6 (DY676-Cys-NrTP6, "mini-crotamine") efficiently penetrated and accumulated in certain lines and cancer cell populations, rendering this NrTP version a promising theranostic probe for imaging cancer heterogeneity and delivery of chemotherapeutics into subpopulations of cancer cells [152].

\subsubsection{Crotalicidin and Elapid CRAMPs}

Crotalicidin (KRFKKFFKKVKKSVKKRLKKIFKKPMVIGVTIPF) is a 34-residue, linear, lysine-rich, amphipathic $\alpha$-helical peptide from the venom gland of the South American rattlesnake $\mathrm{C}$. d. terrificus, which shares high similarity with homologous sequences from the venom gland of diverse species of South American pit viper snakes, such as batroxicidin, lachesicidin and lutzicidin, with only a small number of conserved amino acid 
substitutions; these are collectively named vipericidins [153]. These peptides belong to a family of antimicrobial peptide-denominated CRAMPs (cathelicidin-related antimicrobial peptides), in which members are mature carboxy-terminal products, resulting from the proteolytic cleavage of a longer cathelicidin precursor that includes a signal peptide and a cathelin preproprepeptide, like the human cationic $18 \mathrm{kDa}$ AMP (hCAP18/LL37) [154]. Vipericidins, in general and crotalicidin, in particular, are surprisingly similar to previously characterized Asian elapid CRAMPs, despite South American pit vipers and Asian elapids (cobras and kraits) being geographically and phylogenetically distant venomous snake groups, which evolutionarily diverged millions of years ago. Multiple biological activities have been reported for crotalicidin, vipericidin-related sequences and elapid CRAMPs, with emphasis on antipathogenic and antitumoral properties, as reviewed elsewhere [135,155-157]. The antimicrobial activity ranges from multidrug-resistant clinical isolates to life-threatening viruses, as reported for cathelicidin-OH30 derived from the venom of the king cobra Ophiophagus hannah, as well as venom cathelicidin-BF30 and short derivatives from the banded krait Bungarus fasciatus venom [158,159]. The anti-inflammatory properties of venom cathelicidins have also been observed in in vitro and in vivo models of inflammation for cathelicidin-BF30 [160] and for CRAMPs from the venom of the blue-banded sea snake Hydrophis cyanocyntus, demonstrating the potent antimicrobial activity, associated with immunomodulatory effects of snake venom cathelicidins [161,162]. Short peptide fragments of snake venom cathelicidins have been prepared, displaying different levels of activity and efficacy against a range of microbes, including viruses [163], multidrug-resistant bacteria, pathogenic yeasts and biofilms [164-167].

The interaction of crotalicidin and elapid CRAMPs with biological membranes and biomimetics has been demonstrated for native, full sequences and short-derived peptide fragments and the ability for plasma membrane perturbation is associated with the mechanism of antimicrobial activity [168-172], as well as their antitumor effects, as determined experimentally in vitro with a variety of cancer cell lines [173,174]. Indeed, the cell penetration ability after membrane permeation has been verified for some venom cathelicidins and downsized analogs. For instance, Cbf-K16 and Cbf-A7A13, that is, cathelicidin- BF30, in which Asp at position 16 was substituted for $\mathrm{K}$ and Lys7 and Arg13 were replaced with Ala residues, was shown to bind with high affinity to bacterial DNA after penetrating the cytoplasmic membrane in vitro [175]. The fluorescent-labeled crotalicidin and the parental dodecapeptide (Ctn[15-34], KKRLKKIFKKPMVIGVTIPF-amide), conjugated with rhodamine B and/or fluorescein, accumulated in the plasma membrane, cytoplasm and the nucleus of prokaryotic and eukaryotic cells (pathogenic yeasts and tumor cells) $[170,176]$. Moreover, the internalization and interaction with intracellular targets, metabolic pathways and signaling reportedly contributed to the underlying mechanisms of action of native crotalicidin and short peptide derivatives $[174,176]$. These multiple effects of membrane permeation, cellular internalization and interaction with subcellular targets, pathways and signaling reportedly reinforce the selective microbial killing and selective cytotoxicity against cancer cells over healthy cells. Therefore, snake venom cathelicidins and analogs are an interesting class of peptides with cell penetration properties for development and application in biomedicine and pharmaceutical biotechnology.

\subsubsection{Cardiotoxin}

Cardiotoxins comprise a group of membrane-interacting, three-finger cationic toxins, with approximately 60-residue, found in the venom of different species of cobra (e.g., Naja atra, N. oxiana and N. mossambica mossambica), which are cytotoxic to several eukaryotic cells. A mechanistic feature of interaction distinguishing cardiotoxins from other membrane-active $\alpha$-helical amphipathic peptides and toxins is the fact that the hydrophobic tips of their $\beta$-sheet loops in the three-finger structures are inserted into membranes [177]. Accumulating experimental evidence has indicated that the biological effects of cardiotoxins are not completely dependent on direct plasma membrane damage but also involve modulation of intracellular signaling and, notably, cell penetration and disruption 
of organelle structures and functions, such as lysosomes and mitochondria [178-180]. For instance, cardiotoxins from the venoms of monocled cobra N. kaouthia and Caspian cobra $\mathrm{N}$. oxiana, conjugated to rhodamine, were localized mainly in the lysosomes of human lung adenocarcinoma (A549) and promyelocytic leukemia (HL60) cells after membrane translocation and organelle accumulation [179], whereas rhodamine-labeled cardiotoxin VII4, derived from the Mozambique spitting cobra N. mossambica mossambica, translocated to the mitochondria and induced mitochondrial fragmentation in mouse primary cortical neurons and human neuroblastoma (SH-SY5Y) cells [180].

\subsubsection{Phospholipase $A_{2}$}

Secreted phospholipases $\mathrm{A}_{2}\left(\mathrm{sPLA}_{2}\right)$ are venom components widely distributed in organisms of all kingdoms, from cnidarians and insects (bees, wasps and ants) to arachnids and venomous snakes [181-184]. Based on their structure-activity, venom PLA2 are classified into distinct types that include enzymes that cause hydrolysis of glycerophospholipids and damage cell membranes, as well as toxins devoid of enzymatic activity that cause neurotoxicity and immunomodulation, inflammation and pain. Mendes and collaborators prepared short cationic (13-mer) peptides derived from the C-terminal region of the Lys49 PLA2 from the venom of the broad-banded copperhead snake Agkistrodon contortrix laticinctus, by replacing the natural lysine residues (KKYKAYFKFKCKK-amide) with arginine (RRYRAYFRFRCRR-amide); this imparted this engineered peptide characteristics of CPPs and AMPs and revealed an effective leishmanicidal activity [185].

\subsubsection{BPP-like}

Bradykinin-potentiating peptides (BPPs) comprise a family of 5- to 14-residue prolinerich peptides found in the venom of pit vipers, wasps and frog skin. The main biological activity of these oligopeptides is the inhibition of the angiotensin-converting enzyme of the angiotensin system that regulates human blood pressure and, consequently, induces the severe hypotensive effect of the Bothrops venom [186]. Using a combination of size exclusion chromatography and liposome uptake, Sciani and colleagues [187] identified BPP-13a ( $<$ EGGWPRPGEIPP, where $<$ E is pyroglutamic acid) from the $B$. jararaca venom that demonstrated potential cell-penetrating abilities. To confirm this finding, a fluorescent analog was prepared by conjugation of AlexaFluor ${ }^{\circledR} 488$ with desPyroglutamic1-BPP13a (desPyr-BPP13a; H2N-GGWPRPGPEIPPOH) analog and translocation into the cytoplasm of human melanoma tumor (SK-MEL-28 and A2058) cells was observed by fluorescence microscopy, with no detectable cytotoxicity.

Table 4 summarizes examples of peptides and derivatives from fish and amphibian secretions and snake venom, with cell-penetrating properties and cargo delivery capacity.

Table 4. Examples of peptides and derivatives from fish and amphibian secretion and snake venom, with cell-penetrating and cargo delivery capacity.

\begin{tabular}{|c|c|c|c|c|c|c|}
\hline Peptide & Sequence $^{\text {a }}$ & Size & $\begin{array}{l}\text { Major Structural } \\
\text { Features }^{b}\end{array}$ & $\begin{array}{l}\text { Mechanism(s) } \\
\text { of Cell } \\
\text { Penetration }\end{array}$ & $\begin{array}{c}\text { Cargo } \\
\text { Delivery }\end{array}$ & Ref. \\
\hline $\begin{array}{c}\text { Fish } \\
\text { Ac-Pardaxin P5 }\end{array}$ & Ac-GFFALIPKIISSPLFKTLLSAVGSALSSSGDQE & 33 & Hydrophobic helix & DT, PF & FD & [117] \\
\hline $\begin{array}{c}\text { Amphibian } \\
\text { bombesin } \\
\text { Tat-K3-bombesin }\end{array}$ & $\begin{array}{c}\text { EQKLGNQWAVGHLM-NH }{ }_{2} \\
\text { RKKRRQRRRGGCGEQKLGNQWAVGHLM-NH }{ }_{2}\end{array}$ & $\begin{array}{l}14 \\
27\end{array}$ & $\begin{array}{l}\text { helical harpin } \\
\text { Chimera }\end{array}$ & $\begin{array}{l}\mathrm{RM} \\
\mathrm{RM}\end{array}$ & $\dot{\mathrm{RD}}$ & $\begin{array}{c}{[118-120]} \\
{[124]}\end{array}$ \\
\hline $\begin{array}{l}\text { Snake } \\
\text { Crotamine }\end{array}$ & YKQCHKKGGHCFPKEKICLPPSSDFGKMDCRWRWKCCKKGSG & 42 & $\beta$-defensin fold & multiple & $\mathrm{FD}, \mathrm{CI}$ & [138] \\
\hline NrTP1 & YKQCHKKGGKKGSG & 14 & $\begin{array}{c}\mathrm{N} \leftrightarrow \mathrm{C} \text { splice } \\
\text { variant }\end{array}$ & multiple & FD & {$[146,147]$} \\
\hline $\begin{array}{l}\text { NrTP6 } \\
\text { DY676-NrTP6 }\end{array}$ & $\begin{array}{l}\text { YKQSHKKGGKKGSG } \\
\text { C-YKQSHKKGGKKGSG }\end{array}$ & $\begin{array}{l}14 \\
15\end{array}$ & $\begin{array}{l}\text { NrTP1 Cys } \Delta \text { Ser } \\
\quad \text { Extra Cys }\end{array}$ & multiple & $\begin{array}{l}\mathrm{FD}, \mathrm{EZ} \\
\mathrm{IR}\end{array}$ & $\begin{array}{l}{[148]} \\
{[152]}\end{array}$ \\
\hline CyLop-1 & CRWRWKCCKK & 10 & $\begin{array}{l}\text { Encrypted } \\
\text { sequence }\end{array}$ & DT, ED & FD & [145] \\
\hline
\end{tabular}


Table 4. Cont.

\begin{tabular}{|c|c|c|c|c|c|c|}
\hline Peptide & Sequence $^{\mathrm{a}}$ & Size & $\begin{array}{l}\text { Major Structural } \\
\text { Features }{ }^{b}\end{array}$ & $\begin{array}{c}\text { Mechanism(s) } \\
\text { of Cell } \\
\text { Penetration c }\end{array}$ & $\begin{array}{c}\text { Cargo } \\
\text { Delivery } \mathrm{d}\end{array}$ & Ref. \\
\hline Crotalicidin & KRFKKFFKKVKKSVKKRLKKIFKKPMVIGVTIPF & 34 & $\begin{array}{l}\text { Amphipathic } \\
\alpha \text {-helix }\end{array}$ & DT, PF & FD & [176] \\
\hline Ctn $[15-34]$ & KKRLKKIFKKPMVIGVTIPF-NH ${ }_{2}$ & 20 & $\begin{array}{l}\text { C-terminal } \\
\text { fragment }\end{array}$ & $\mathrm{DT}, \mathrm{PF}$ & FD & {$[170,176]$} \\
\hline cathelicidin- BF30 & KFFRKLKKSVKKRAKEFFKKPRVIGVSIPF & 30 & Shorter analogue & DT, PF & - & \\
\hline Cardiotoxin & $\begin{array}{l}\text { LKCNKLIPLAYKTCPAGKNLCYKMFMVSNKTVPVKRGCID } \\
\text { ACPKNSLLVKYVCCNTDRCN }\end{array}$ & 60 & Three-finger fold & DT, HI & FD & [179] \\
\hline $\mathrm{PLA}_{2}$ C-terminal & KKYKAYFKFKCKK-NH $\mathrm{N}_{2}$ & 13 & $\begin{array}{l}\text { C-terminal } \\
\text { fragment }\end{array}$ & DT, MD & - & [185] \\
\hline $\mathrm{PLA}_{2} \underset{\text { BPP-13a }}{\text { fragment }} \mathrm{K} \rightarrow \mathrm{R}$ & $\begin{array}{c}\text { RRYRAYFRFRCRR-NH }_{2} \\
<\text { EGGWPRPGEIPP }\end{array}$ & $\begin{array}{l}13 \\
12\end{array}$ & $\begin{array}{l}\text { Mutant } K \rightarrow R \\
\text { Native }\end{array}$ & $\begin{array}{l}\text { DT, MD } \\
\text { DT (?) }\end{array}$ & $\begin{array}{l}- \\
-\end{array}$ & $\begin{array}{l}{[185]} \\
{[187]}\end{array}$ \\
\hline desPyr-BPP13a & GGWPRPGPEIPP & 12 & Mutant analogue & DT (?) & FD & {$[187]$} \\
\hline
\end{tabular}

Notes: ${ }^{a}$ Ac, acetylated; $-\mathrm{NH}_{2}$, amidated; $<$ E, pyroglutamic; DT, direct translocation; ${ }^{\mathrm{b}} \mathrm{N} \leftrightarrow \mathrm{C}$, spliced derivative of crotamine, comprising the N-terminal residues 1 to 9 and C-terminal 38 to 42 ([1-9] [38-42]); NrTP6, a NrTP1 with a Cys-Ser replacement; DY676, near-infrared dye; ${ }^{c}$ DT, direct translocation; PF, pore forming; RM, receptor-mediated endocytosis; multiple, more than a single mechanism of cell entry, that can involve direct translocation and endocytosis; ED, endocytosis; HI, hydrophobic insertion; MD, membrane-disruptive cell uptake; d FD, fluorescent dyes; RD, radionuclides; EZ, enzymes; IR, infrared dye; “_" not applicable;

\section{Discussion}

In nature, a wide variety of toxins from microbial and animal origins affect eukaryotic cells either by interfering directly with and disrupting the cytoplasmic membrane or through interaction with integral membrane components, such as receptors and membrane microdomains, to gain access to the cytoplasm and interfere with subcellular structures and intracellular signaling. Well-known examples include the bacterial pore forming toxins (PFTs) and binary bacterial toxins. In the first group, single chain toxins with amphipathic $\alpha$-helices ( $\alpha$-PFTs) or amphipathic $\beta$-hairpins ( $\beta$-PFTs) oligomerize on phospholipid membranes and form pores or channels through which cellular contents extravasate. These cytolytic bacterial toxins are produced and secreted by a large number of Gram-negative and Gram-positive bacteria [188]. In the second group, in-solution formed after activation or preformed "A-B" binary toxins act by binding to their correspondent receptors through the " $\mathrm{B}$ " docking domain and translocate a catalytic " $\mathrm{A}$ "' component into the cytosol, which disrupts ribosome structure and function and consequently protein synthesis of targeted cells [189]. Pore-forming cytolysins are also found in a variety of animal venoms, particularly in venom from arachnids (scorpion and spiders), hymenopterans (ants, bees and wasps) [190-192] and cnidarians (anemones, corals and jellyfishes), including zoanthid toxins belonging to the superfamily of membrane attack complex-perforin/cholesteroldependent cytolysins (MACPF/CDC) [193-195]. Concurrently, antimicrobial peptides from diverse biological tissues, secretions and organisms of all kingdom also exert their effect essentially by membrane permeation and therefore, share a convergent mechanism of action with PFTs, despite their distinct target cell selectivity [196]. Thus, microbial PFTs, membrane-disruptive (cytolytic) venom peptides and AMPs that accumulate initially on the membrane surface by electrostatic attraction and/or hydrophobic interactions, form pores, permeabilize membranes and eventually enter into target cells and act intracellularly, in some cases $[40,197]$. In contrast, a handful of binary bacterial toxins and some plant toxins deliver the intracellular active toxin domain into the cytoplasm of target cells via receptormediated endocytosis and various intracellular trafficking pathways [189,197-199].

Non-disruptive membrane translocation and cell penetration of venom peptides are less common, with some examples emerging in the last decades. Several of these venom peptides that can penetrate cells by direct translocation and/or receptor-dependent and/or receptor-independent endocytosis to exert their effect on intracellular targets were presented herein. In addition, venom peptides that can penetrate cells by membrane-disruptive means, such as anoplin, lycosin- 1 and melittin from arthropod venom; pardaxin from fish secretion; and crotalicidin, from snake venom, were also listed. Importantly, native animal venom peptides and toxins with cell-penetrating activity have been characterized and CPPs derived from them conceived through a variety of structural modifications of their native sequences. These structural modifications of cell-penetrating venom peptides include peptide downsizing, amino acid residue replacement, structural stabilization and production 
of chimeras, which mostly reduced peptide cytotoxicity, maintained the target selectivity and enhanced the cellular penetrability and the capacity of intracellular cargo transport and delivery. Undoubtedly, a distinction should be made between pore-forming, cytolytic peptides that can gain eventual entry into the cells and toxins through disruptive mechanisms from venom peptides and analogs that penetrate cells by non-disruptive, direct translocations and receptor-mediated and receptor-independent endocytosis. Despite this, both classes of membrane-interacting toxins can be engineered to excise the peptide motif responsible for membrane interaction and translocation, as observed in several examples presented herein.

\section{Conclusions}

Animal venoms are a blend of bioactive peptides, among other organic and enzymatic components, that in combination and synergistically disrupt the physiological processes of prey and/or victims. Apart from several families of bioactive peptides and proteins that act in a variety of biological processes and systems, such as neurotransmission, blood coagulation, immune modulation and tissue integrity, venom peptides and toxins with the intrinsic ability to penetrate cells by membrane-disruptive and non-disruptive mechanisms have been disclosed. These cell-penetrating venom peptides and toxin derivatives have expanded the library of animal toxins that act intracellularly and have presently served and will be useful in future, for biomedical and biotechnological applications.

\section{Future Direction}

The designed CPP from venom peptides have found applications in biomedicine and biopharmaceutical biotechnology, in diagnostics to detect populations of diseased cells or tissues, in therapy to induce selective cell death through molecular deliver of cellimpermeant drugs, organic compounds, radionuclides and crystal and metallic nanoparticles. By combining information on the cell penetrability of venom peptides and derivatives, it is expected this review will draw more attention to animal toxins and venom peptides that act intracellularly and promote their own passage across biological membranes to exert their effects. Therefore, discoveries of cell penetrating venom peptides and animal toxins will continue to contribute to the basic and applied research in this expanding field of CPPs derived from components of poisonous and venomous animals.

\section{Materials and Methods}

The preparation of this systematic review followed the recommendation of the PRISMA Statement for Reporting Systematic Reviews and Meta-Analyses of Studies that Evaluate Health Care Interventions: Explanation and Elaboration [200]. The search terms were: "cell penetrating peptide AND animal toxin" that yielded 140 entries from PUBMED. After selecting most relevant reports that adhered to the scope of this review, 50 general articles were excluded, including studies about "crotamine." Considering the terms "crotamine AND cell-penetrating peptides" as search items, 26 additional articles were included. Then, the database was again queried to find fundamental and general studies on representative venom peptides with cell-penetrating properties that were found in the initial search, to obtain more complete information about their respective animal venom sources, structural features and main pharmacological activities, resulting in the final references, as listed in this manuscript.

Funding: Research grants were from the National Council of Research and Development, (CNPq), the Ministry of Science, Technology and Innovation (MCTI), grant numbers 307733/2016-5 and 431077/2016-9 (G.R.-B.). G.R.-B. is a senior researcher from CNPq/MCTI.

Data Availability Statement: Data sharing not applicable. 
Acknowledgments: The author is grateful to the Coordination for the Improvement of Higher Education Personnel (CAPES), the Ministry of Education and Culture (MEC), Federal Government of Brazil for the open journal platform (https:/ / www-periodicos-capes-gov-br.ezl.periodicos.capes.gov. br/index.php? (accessed on 15 November 2020)) permanently available for the academic community.

Conflicts of Interest: The author declares no conflict of interest. The funders had no role in the design of the study; in the collection, analyses or interpretation of data; in the writing of the manuscript or in the decision to publish the results.

\section{References}

1. Singh, S.; Peláez, F. Biodiversity, chemical diversity and drug discovery. Prog. Drug Res. 2008, 65, 141, 143-174. [CrossRef] [PubMed]

2. Nelsen, D.R.; Nisani, Z.; Cooper, A.M.; Fox, G.A.; Gren, E.C.; Corbit, A.G.; Hayes, W.K. Poisons, toxungens and venoms: Redefining and classifying toxic biological secretions and the organisms that employ them. Biol. Rev. Camb. Philos. Soc. 2014, 89, 450-465. [CrossRef] [PubMed]

3. Modahl, C.M.; Brahma, R.K.; Koh, C.Y.; Shioi, N.; Kini, R.M. Omics Technologies for Profiling Toxin Diversity and Evolution in Snake Venom: Impacts on the Discovery of Therapeutic and Diagnostic Agents. Annu. Rev. Anim. Biosci. 2020, 8, 91-116. [CrossRef] [PubMed]

4. Kazuma, K.; Masuko, K.; Konno, K.; Inagaki, H. Combined Venom Gland Transcriptomic and Venom Peptidomic Analysis of the Predatory Ant Odontomachus monticola. Toxins 2017, 9, 323. [CrossRef]

5. Wiezel, G.A.; Shibao, P.Y.T.; Cologna, C.T.; Filho, M.R.; Vieira, U.C.; De Pauw, E.; Quinton, L.; Arantes, E.C. In-Depth Venome of the Brazilian Rattlesnake Crotalus durissus terrificus: An Integrative Approach Combining Its Venom Gland Transcriptome and Venom Proteome. J. Proteome Res. 2018, 17, 3941-3958. [CrossRef]

6. $\quad$ Liao, Q.; Gong, G.; Poon, T.C.W.; Ang, I.L.; Lei, K.M.K.; Siu, S.W.I.; Wong, C.T.T.; Baptista, R.G.; Lee, S.M. Combined transcriptomic and proteomic analysis reveals a diversity of venom-related and toxin-like peptides expressed in the mat anemone Zoanthus natalensis (Cnidaria, Hexacorallia). Arch. Toxicol. 2019, 93, 1745-1767. [CrossRef]

7. Carreto, R.S.; Estrella, V.R.; Bobadilla, P.T.; Navarro, L.A.; Sarabia, B.J.; Piñera, R.E.; Verleyen, J.J.; Rodríguez, E.; Almazán, R.C. Transcriptomic and Proteomic Analysis of the Tentacles and Mucus of Anthopleura dowii Verrill, 1869. Mar. Drugs 2019, 17, 436. [CrossRef]

8. Aili, S.R.; Touchard, A.; Hayward, R.; Robinson, S.D.; Pineda, S.S.; Lalagüe, H.; Vetter, I.; Undheim, E.A.B.; Kini, R.M.; Escoubas, P.; et al. An Integrated Proteomic and Transcriptomic Analysis Reveals the Venom Complexity of the Bullet Ant Paraponera clavata. Toxins 2020, 12, 324. [CrossRef]

9. Dalmazzone, S. Economics and Policy of Biodiversity Loss. In Sustainable Development and Environmental Management: Experiences and Case Studies; Clini, C., Musu, I., Gullino, M.L., Eds.; Springer: Dordrecht, The Netherlands, 2008; pp. 451-466. [CrossRef]

10. Kessler, P.; Marchot, P.; Silva, M.; Servent, D. The three-finger toxin fold: A multifunctional structural scaffold able to modulate cholinergic functions. J. Neurochem. 2017, 142, 7-18. [CrossRef]

11. Shafee, T.M.A.; Lay, F.T.; Phan, T.K.; Anderson, M.A.; Hulett, M.D. Convergent evolution of defensin sequence, structure and function. Cell. Mol. Life Sci. 2017, 74, 663-682. [CrossRef]

12. Zhang, S.K.; Song, J.W.; Gong, F.; Li, S.B.; Chang, H.Y.; Xie, H.M.; Gao, H.W.; Tan, Y.X.; Ji, S.P. Design of an $\alpha$-helical antimicrobial peptide with improved cell-selective and potent anti-biofilm activity. Sci. Rep. 2016, 6, 7394. [CrossRef]

13. Joliot, A.; Prochiantz, A. Transduction peptides: From technology to physiology. Nat. Cell Biol. 2004, 6, 189-196. [CrossRef]

14. Mándity, I.M.; Fülöp, F. An overview of peptide and peptoid foldamers in medicinal chemistry. Expert Opin. Drug Discov. 2015 10, 1163-1177. [CrossRef] [PubMed]

15. Kalafatovic, D.; Giralt, E. Cell-Penetrating Peptides: Design Strategies beyond Primary Structure and Amphipathicity. Molecules 2017, 22, 1929. [CrossRef] [PubMed]

16. Sandvig, K.; van Deurs, B. Delivery into cells: Lessons learned from plant and bacterial toxins. Gene Ther. 2005, 12, 865-872. [CrossRef] [PubMed]

17. Baptista, R.G.; Kerkis, A.; Silva, P.Á.R.; Hayashi, M.A.F.; Kerkis, I.; Tetsuo, Y. Membrane-translocating peptides and toxins: From nature to bedside. J. Braz. Chem. Soc. 2008, 19, 211-225. [CrossRef]

18. Sandvig, K.; Bergan, J.; Kavaliauskiene, S.; Skotland, T. Lipid requirements for entry of protein toxins into cells. Prog. Lipid Res. 2014, 54, 1-13. [CrossRef]

19. Bechara, C.; Sagan, S. Cell-penetrating peptides: 20years later, where do we stand? FEBS Lett. 2013, 587, 1693-1702. [CrossRef] [PubMed]

20. Copolovici, D.M.; Langel, K.; Eriste, E.; Langel, Ü. Cell-Penetrating Peptides: Design, Synthesis and Applications. ACS Nano 2014, 8, 1972-1994. [CrossRef]

21. Gautam, A.; Singh, H.; Tyagi, A.; Chaudhary, K.; Kumar, R.; Kapoor, P.; Raghava, G.P. CPPsite: A curated database of cell penetrating peptides. Database J. Biol. Databases Curation 2012, 2012. [CrossRef]

22. Agrawal, P.; Bhalla, S.; Usmani, S.S.; Singh, S.; Chaudhary, K.; Raghava, G.P.; Gautam, A. CPPsite 2.0: A repository of experimentally validated cell-penetrating peptides. Nucleic Acids Res. 2016, 44, D1098-D1103. [CrossRef]

23. Kardani, K.; Bolhassani, A. Cppsite 2.0: An Available Database of Experimentally Validated Cell-Penetrating Peptides Predicting their Secondary and Tertiary Structures. J. Mol. Biol. 2020, 6703. [CrossRef] [PubMed] 
24. Wei, H.H.; Yang, W.; Tang, H.; Lin, H. The Development of Machine Learning Methods in Cell-Penetrating Peptides Identification: A Brief Review. Curr. Drug Metab. 2019, 20, 217-223. [CrossRef] [PubMed]

25. Yamashita, H.; Kato, T.; Oba, M.; Misawa, T.; Hattori, T.; Ohoka, N.; Tanaka, M.; Naito, M.; Kurihara, M.; Demizu, Y. Development of a Cell-penetrating Peptide that Exhibits Responsive Changes in its Secondary Structure in the Cellular Environment. Sci. Rep. 2016, 6. [CrossRef] [PubMed]

26. Eiríksdóttir, E.; Konate, K.; Langel, Ü.; Divita, G.; Deshayes, S. Secondary structure of cell-penetrating peptides controls membrane interaction and insertion. Biochim. Biophys. Acta (BBA) Biomembr. 2010, 1798, 1119-1128. [CrossRef]

27. Milletti, F. Cell-penetrating peptides: Classes, origin and current landscape. Drug Discov. Today 2012, 17, 850-860. [CrossRef]

28. Borrelli, A.; Tornesello, A.L.; Tornesello, M.L.; Buonaguro, F.M. Cell Penetrating Peptides as Molecular Carriers for Anti-Cancer Agents. Molecules 2018, 23, 295. [CrossRef]

29. Baptista, R.G.; Campelo, I.S.; Morlighem, J.R.L.; Melo, L.M.; Freitas, V.J.F. Cell-penetrating peptides (CPPs): From delivery of nucleic acids and antigens to transduction of engineered nucleases for application in transgenesis. J. Biotechnol. 2017, 252, 15-26. [CrossRef]

30. Huang, Y.W.; Lee, H.J. 13-Cell-penetrating peptides for medical theranostics and targeted drug delivery. In Peptide Applications in Biomedicine, Biotechnology and Bioengineering; Koutsopoulos, S., Ed.; Woodhead Publishing: Cambridge, UK, 2018; pp. 359-370. [CrossRef]

31. Pierantoni, G.M.; Paladino, S. Cell-penetrating peptides: Two faces of the same coin. Biochem. J. 2020, 477, 1363-1366. [CrossRef]

32. Ruseska, I.; Zimmer, A. Internalization mechanisms of cell-penetrating peptides. Beilstein J. Nanotechnol. 2020, 11, 101-123. [CrossRef]

33. Tünnemann, G.; Martin, R.M.; Haupt, S.; Patsch, C.; Edenhofer, F.; Cardoso, M.C. Cargo-dependent mode of uptake and bioavailability of TAT-containing proteins and peptides in living cells. FASEB J. Off. Publ. Fed. Am. Soc. Exp. Biol. 2006, 20, 1775-1784. [CrossRef]

34. Andaloussi, E.S.; Järver, P.; Johansson, H.J.; Langel, U. Cargo-dependent cytotoxicity and delivery efficacy of cell-penetrating peptides: A comparative study. Biochem. J. 2007, 407, 285-292. [CrossRef] [PubMed]

35. Hedegaard, S.F.; Derbas, M.S.; Lind, T.K.; Kasimova, M.R.; Christensen, M.V.; Michaelsen, M.H.; Campbell, R.A.; Jorgensen, L.; Franzyk, H.; Cárdenas, M.; et al. Fluorophore labeling of a cell-penetrating peptide significantly alters the mode and degree of biomembrane interaction. Sci. Rep. 2018, 8, 6327. [CrossRef] [PubMed]

36. Patel, S.G.; Sayers, E.J.; He, L.; Narayan, R.; Williams, T.L.; Mills, E.M.; Allemann, R.K.; Luk, L.Y.P.; Jones, A.T.; Tsai, Y.H. Cell-penetrating peptide sequence and modification dependent uptake and subcellular distribution of green florescent protein in different cell lines. Sci. Rep. 2019, 9, 6298. [CrossRef] [PubMed]

37. Yacoub, T.; Rima, M.; Karam, M.; Fajloun, J. Antimicrobials from Venomous Animals: An Overview. Molecules 2020, $25,2402$. [CrossRef] [PubMed]

38. Splith, K.; Neundorf, I. Antimicrobial peptides with cell-penetrating peptide properties and vice versa. Eur. Biophys. J. EBJ 2011, 40, 387-397. [CrossRef] [PubMed]

39. Neundorf, I. Antimicrobial and Cell-Penetrating Peptides: How to Understand Two Distinct Functions Despite Similar Physicochemical Properties. Adv. Exp. Med. Biol. 2019, 1117, 93-109. [CrossRef] [PubMed]

40. Le, C.F.; Fang, C.M.; Sekaran, S. Intracellular Targeting Mechanisms by Antimicrobial Peptides. Antimicrob. Agents Chemother. 2017, 61. [CrossRef]

41. Park, C.B.; Yi, K.S.; Matsuzaki, K.; Kim, M.S.; Kim, S.C. Structure-activity analysis of buforin II, a histone H2A-derived antimicrobial peptide: The proline hinge is responsible for the cell-penetrating ability of buforin II. Proc. Natl. Acad. Sci. USA 2000, 97, 8245-8250. [CrossRef]

42. Liang, Y.; Zhang, X.; Yuan, Y.; Bao, Y.; Xiong, M. Role and modulation of the secondary structure of antimicrobial peptides to improve selectivity. Biomater. Sci. 2020, 8, 6858-6866. [CrossRef]

43. Abid, S.N.; Othman, H.; Aissaoui, D.; Aissa, B.R. Anti-tumoral effect of scorpion peptides: Emerging new cellular targets and signaling pathways. Cell Calcium 2019, 80, 160-174. [CrossRef] [PubMed]

44. Rady, I.; Siddiqui, I.A.; Rady, M.; Mukhtar, H. Melittin, a major peptide component of bee venom and its conjugates in cancer therapy. Cancer Lett. 2017, 402, 16-31. [CrossRef] [PubMed]

45. Wehbe, R.; Frangieh, J.; Rima, M.; Obeid, E.D.; Sabatier, J.M.; Fajloun, Z. Bee Venom: Overview of Main Compounds and Bioactivities for Therapeutic Interests. Molecules 2019, 24, 2997. [CrossRef]

46. Shaw, J.E.; Epand, R.F.; Hsu, J.C.; Mo, G.C.; Epand, R.M.; Yip, C.M. Cationic peptide-induced remodelling of model membranes: Direct visualization by in situ atomic force microscopy. J. Struct. Biol. 2008, 162, 121-138. [CrossRef]

47. Hong, J.; Lu, X.; Deng, Z.; Xiao, S.; Yuan, B.; Yang, K. How Melittin Inserts into Cell Membrane: Conformational Changes, Inter-Peptide Cooperation and Disturbance on the Membrane. Molecules 2019, 24, 1775.

48. Jia, H.R.; Zhu, Y.X.; Xu, K.F.; Wu, F.G. Turning Toxicants into Safe Therapeutic Drugs: Cytolytic Peptide-Photosensitizer Assemblies for Optimized In Vivo Delivery of Melittin. Adv. Healthc. Mater. 2018, 7, 380. [CrossRef] [PubMed]

49. Jamasbi, E.; Lucky, S.S.; Li, W.; Hossain, M.A.; Gopalakrishnakone, P.; Separovic, F. Effect of dimerized melittin on gastric cancer cells and antibacterial activity. Amino Acids 2018, 50, 1101-1110. [CrossRef]

50. Luo, L.; Wu, W.; Sun, D.; Dai, H.B.; Wang, Y.; Zhong, Y.; Wang, J.X.; Maruf, A.; Nurhidayah, D.; Zhang, X.J.; et al. Acid-Activated Melittin for Targeted and Safe Antitumor Therapy. Bioconjugate Chem. 2018, 29, 2936-2944. [CrossRef] 
51. Liu, H.; Hu, Y.; Sun, Y.; Wan, C.; Zhang, Z.; Dai, X.; Lin, Z.; He, Q.; Yang, Z.; Huang, P.; et al. Co-delivery of Bee Venom Melittin and a Photosensitizer with an Organic-Inorganic Hybrid Nanocarrier for Photodynamic Therapy and Immunotherapy. ACS Nano 2019, 13, 12638-12652. [CrossRef]

52. Salomone, F.; Cardarelli, F.; Di Luca, M.; Boccardi, C.; Nifosì, R.; Bardi, G.; Di Bari, L.; Serresi, M.; Beltram, F. A novel chimeric cell-penetrating peptide with membrane-disruptive properties for efficient endosomal escape. J. Control. Release 2012, 163, 293-303. [CrossRef]

53. Lee, C.; Jeong, H.; Bae, Y.; Shin, K.; Kang, S.; Kim, H.; Oh, J.; Bae, H. Targeting of M2-like tumor-associated macrophages with a melittin-based pro-apoptotic peptide. J. Immunother. Cancer 2019, 7, 147. [CrossRef] [PubMed]

54. Hou, K.K.; Pan, H.; Lanza, G.M.; Wickline, S.A. Melittin derived peptides for nanoparticle based siRNA transfection. Biomaterials 2013, 34, 3110-3119. [CrossRef] [PubMed]

55. Mills, K.A.; Quinn, J.M.; Roach, S.T.; Palisoul, M.; Nguyen, M.; Noia, H.; Guo, L.; Fazal, J.; Mutch, D.G.; Wickline, S.A.; et al. p5RHH nanoparticle-mediated delivery of AXL siRNA inhibits metastasis of ovarian and uterine cancer cells in mouse xenografts. Sci. Rep. 2019, 9, 4762. [CrossRef] [PubMed]

56. Tan, Y.X.; Chen, C.; Wang, Y.L.; Lin, S.; Wang, Y.; Li, S.B.; Jin, X.P.; Gao, H.W.; Du, F.S.; Gong, F.; et al. Truncated peptides from melittin and its analog with high lytic activity at endosomal $\mathrm{pH}$ enhance branched polyethylenimine-mediated gene transfection. J. Gene Med. 2012, 14, 241-250. [CrossRef]

57. Kyung, H.; Ki, M.H.; Lee, H.J.; Lee, S.J. Enhanced intracellular delivery of macromolecules by melittin derivatives mediated cellular uptake. J. Ind. Eng. Chem. 2018, 58, 290-295. [CrossRef]

58. Konno, K.; Hisada, M.; Fontana, R.; Lorenzi, C.C.; Naoki, H.; Itagaki, Y.; Miwa, A.; Kawai, N.; Nakata, Y.; Yasuhara, T.; et al. Anoplin, a novel antimicrobial peptide from the venom of the solitary wasp Anoplius samariensis. Biochim. Biophys. Acta 2001, 1550, 70-80. [CrossRef]

59. Leung, B.O.; Hitchcock, A.P.; Won, A.; Ianoul, A.; Scholl, A. Imaging interactions of cationic antimicrobial peptides with model lipid monolayers using X-ray spectromicroscopy. Eur. Biophys. J. EBJ 2011, 40, 805-810. [CrossRef]

60. Wu, Y.; Huang, R.; Jin, J.M.; Zhang, L.J.; Zhang, H.; Chen, H.Z.; Chen, L.L.; Luan, X. Advances in the Study of Structural Modification and Biological Activities of Anoplin. Front. Chem. 2020, 8, 519. [CrossRef]

61. Zhong, C.; Gou, S.; Liu, T.; Zhu, Y.; Zhu, N.; Liu, H.; Zhang, Y.; Xie, J.; Guo, X.; Ni, J. Study on the effects of different dimerization positions on biological activity of partial d-Amino acid substitution analogues of Anoplin. Microb. Pathog. 2020, 139, 103871. [CrossRef]

62. Tian, X.; Sun, F.; Zhou, X.R.; Luo, S.Z.; Chen, L. Role of peptide self-assembly in antimicrobial peptides. J. Pept. Sci. 2015, 21, 530-539. [CrossRef]

63. Cong, Y.; Ji, L.; Gao, Y.J.; Liu, F.H.; Cheng, D.B.; Hu, Z.; Qiao, Z.Y.; Wang, H. Microenvironment-Induced In Situ Self-Assembly of Polymer-Peptide Conjugates That Attack Solid Tumors Deeply. Angew. Chem. Int. Ed. 2019, 58, 4632-4637. [CrossRef] [PubMed]

64. Hirai, Y.; Yasuhara, T.; Yoshida, H.; Nakajima, T.; Fujino, M.; Kitada, C. A new mast cell degranulating peptide "mastoparan" in the venom of Vespula lewisii. Chem. Pharm. Bull. 1979, 27, 1942-1944. [CrossRef]

65. Hirai, Y.; Kuwada, M.; Yasuhara, T.; Yoshida, H.; Nakajima, T. A new mast cell degranulating peptide homologous to mastoparan in the venom of Japanese hornet (Vespa xanthoptera). Chem. Pharm. Bull. 1979, 27, 1945-1946. [CrossRef]

66. Pooga, M.; Hällbrink, M.; Zorko, M.; Langel, U. Cell penetration by transportan. FASEB J. Off. Publ. Fed. Am. Soc. Exp. Biol. 1998, 12, 67-77. [CrossRef]

67. Soomets, U.; Lindgren, M.; Gallet, X.; Hällbrink, M.; Elmquist, A.; Balaspiri, L.; Zorko, M.; Pooga, M.; Brasseur, R.; Langel, U. Deletion analogues of transportan. Biochim. Biophys. Acta 2000, 1467, 165-176. [CrossRef]

68. Howl, J.; Howl, L.; Jones, S. The cationic tetradecapeptide mastoparan as a privileged structure for drug discovery: Enhanced antimicrobial properties of mitoparan analogues modified at position-14. Peptides 2018, 101, 95-105. [CrossRef]

69. Lindberg, M.; Jarvet, J.; Langel, U.; Gräslund, A. Secondary structure and position of the cell-penetrating peptide transportan in SDS micelles as determined by NMR. Biochemistry 2001, 40, 3141-3149. [CrossRef]

70. Yandek, L.E.; Pokorny, A.; Almeida, P.F. Wasp mastoparans follow the same mechanism as the cell-penetrating peptide transportan 10. Biochemistry 2009, 48, 7342-7351. [CrossRef] [PubMed]

71. Song, J.; Kai, M.; Zhang, W.; Zhang, J.; Liu, L.; Zhang, B.; Liu, X.; Wang, R. Cellular uptake of transportan 10 and its analogs in live cells: Selectivity and structure-activity relationship studies. Peptides 2011, 32, 1934-1941. [CrossRef] [PubMed]

72. Suhorutsenko, J.; Oskolkov, N.; Arukuusk, P.; Kurrikoff, K.; Eriste, E.; Copolovici, D.M.; Langel, Ü. Cell-Penetrating Peptides, PepFects, Show No Evidence of Toxicity and Immunogenicity In Vitro and In Vivo. Bioconjugate Chem. 2011, 22, 2255-2262. [CrossRef]

73. Zhang, C.; Ren, W.; Liu, Q.; Tan, Z.; Li, J.; Tong, C. Transportan-derived cell-penetrating peptide delivers siRNA to inhibit replication of influenza virus in vivo. Drug Des. Dev. Ther. 2019, 13, 1059-1068. [CrossRef]

74. Pepe, D.; Carvalho, V.F.; McCall, M.; de Lemos, D.P.; Lopes, L.B. Transportan in nanocarriers improves skin localization and antitumor activity of paclitaxel. Int. J. Nanomed. 2016, 11, 2009-2019. [CrossRef]

75. Eriksson, O.S.; Geörg, M.; Sjölinder, H.; Sillard, R.; Lindberg, S.; Langel, U.; Jonsson, A.B. Identification of cell-penetrating peptides that are bactericidal to Neisseria meningitidis and prevent inflammatory responses upon infection. Antimicrob. Agents Chemother. 2013, 57, 3704-3712. [CrossRef] [PubMed] 
76. Xie, J.; Gou, Y.; Zhao, Q.; Li, S.; Zhang, W.; Song, J.; Mou, L.; Li, J.; Wang, K.; Zhang, B.; et al. Antimicrobial activities and action mechanism studies of transportan 10 and its analogues against multidrug-resistant bacteria. J. Pept. Sci. Off. Publ. Eur. Pept. Soc. 2015, 21, 599-607. [CrossRef] [PubMed]

77. Ruczyński, J.; Rusiecka, I.; Turecka, K.; Kozłowska, A.; Alenowicz, M.; Gagało, I.; Kawiak, A.; Rekowski, P.; Waleron, K.; Kocić, I. Transportan 10 improves the pharmacokinetics and pharmacodynamics of vancomycin. Sci. Rep. 2019, 9, 3247. [CrossRef]

78. Jones, S.; Martel, C.; Casagrande, B.A.S.; Brenner, C.; Howl, J. Mitoparan and target-selective chimeric analogues: Membrane translocation and intracellular redistribution induces mitochondrial apoptosis. Biochim. Biophys. Acta 2008, 1783, 849-863. [CrossRef] [PubMed]

79. Jones, S.; Howl, J. Enantiomer-specific bioactivities of peptidomimetic analogues of mastoparan and mitoparan: Characterization of inverso mastoparan as a highly efficient cell penetrating peptide. Bioconjugate Chem. 2012, 23, 47-56. [CrossRef]

80. Richardson, A.; Muir, L.; Mousdell, S.; Sexton, D.; Jones, S.; Howl, J.; Ross, K. Modulation of mitochondrial activity in HaCaT keratinocytes by the cell penetrating peptide Z-Gly-RGD(DPhe)-mitoparan. BMC Res. Notes 2018, 11, 82. [CrossRef]

81. Kozlov, S.A.; Vassilevski, A.A.; Feofanov, A.V.; Surovoy, A.Y.; Karpunin, D.V.; Grishin, E.V. Latarcins, Antimicrobial and Cytolytic Peptides from the Venom of the Spider Lachesana tarabaevi (Zodariidae) That Exemplify Biomolecular Diversity. J. Biol. Chem. 2006, 281, 20983-20992. [CrossRef]

82. Ponnappan, N.; Chugh, A. Cell-penetrating and cargo-delivery ability of a spider toxin-derived peptide in mammalian cells. Eur. J. Pharm. Biopharm. 2017, 114, 145-153. [CrossRef]

83. Budagavi, D.P.; Zarin, S.; Chugh, A. Antifungal activity of Latarcin 1 derived cell-penetrating peptides against Fusarium solani. Biochim. Biophys. Acta Biomembr. 2018, 1860, 250-256. [CrossRef] [PubMed]

84. Tan, H.; Ding, X.; Meng, S.; Liu, C.; Wang, H.; Xia, L.; Liu, Z.; Liang, S. Antimicrobial potential of lycosin-I, a cationic and amphiphilic peptide from the venom of the spider Lycosa singorensis. Curr. Mol. Med. 2013, 13, 900-910. [CrossRef] [PubMed]

85. Liu, Z.; Deng, M.; Xiang, J.; Ma, H.; Hu, W.; Zhao, Y.; Li, D.W.; Liang, S. A novel spider peptide toxin suppresses tumor growth through dual signaling pathways. Curr. Mol. Med. 2012, 12, 1350-1360. [CrossRef] [PubMed]

86. Wang, L.; Wang, Y.J.; Liu, Y.Y.; Li, H.; Guo, L.X.; Liu, Z.H.; Shi, X.L.; Hu, M. In vivo Potential of Lycosin-I as an Alternative Antimicrobial Drug for Treatment of Multidrug-Resistant Acinetobacter baumannii Infections. Antimicrob. Agents Chemother. 2014, 58, 6999. [CrossRef]

87. Tan, H.; Luo, W.; Wei, L.; Chen, B.; Li, W.; Xiao, L.; Manzhos, S.; Liu, Z.; Liang, S. Quantifying the Distribution of the Stoichiometric Composition of Anticancer Peptide Lycosin-I on the Lipid Membrane with Single Molecule Spectroscopy. J. Phys. Chem. B 2016, 120, 3081-3088. [CrossRef] [PubMed]

88. Tan, H.; Huang, Y.; Xu, J.; Chen, B.; Zhang, P.; Ye, Z.; Liang, S.; Xiao, L.; Liu, Z. Spider Toxin Peptide Lycosin-I Functionalized Gold Nanoparticles for in vivo Tumor Targeting and Therapy. Theranostics 2017, 7, 3168-3178. [CrossRef]

89. Zhang, P.; Ma, J.; Yan, Y.; Chen, B.; Liu, B.; Jian, C.; Zhu, B.; Liang, S.; Zeng, Y.; Liu, Z. Arginine modification of lycosin-I to improve inhibitory activity against cancer cells. Org. Biomol. Chem. 2017, 15, 9379-9388. [CrossRef]

90. De Bin, J.A.; Maggio, J.E.; Strichartz, G.R. Purification and characterization of chlorotoxin, a chloride channel ligand from the venom of the scorpion. Am. J. Physiol. 1993, 264, C361-C369. [CrossRef] [PubMed]

91. Deshane, J.; Garner, C.C.; Sontheimer, H. Chlorotoxin inhibits glioma cell invasion via matrix metalloproteinase-2. J. Biol. Chem. 2003, 278, 4135-4144. [CrossRef]

92. The MICAD Research Team, N. 131I-Chlorotoxin. 2007 Jul 17. Molecular Imaging and Contrast Agent Database (MICAD). Available online: https:/ / www.ncbi.nlm.nih.gov/books/NBK23317/ (accessed on 8 August 2007).

93. Cohen, G.; Burks, S.R.; Frank, J.A. Chlorotoxin-A Multimodal Imaging Platform for Targeting Glioma Tumors. Toxins 2018, 10, 496. [CrossRef]

94. Wiranowska, M.; Colina, L.; Johnson, J. Clathrin-mediated entry and cellular localization of chlorotoxin in human glioma. Cancer Cell Int. 2011, 11, 27. [CrossRef]

95. Ojeda, P.G.; Henriques, S.T.; Pan, Y.; Nicolazzo, J.A.; Craik, D.J.; Wang, C.K. Lysine to arginine mutagenesis of chlorotoxin enhances its cellular uptake. Biopolymers 2017, 108. [CrossRef] [PubMed]

96. Fajloun, Z.; Kharrat, R.; Chen, L.; Lecomte, C.; Di Luccio, E.; Bichet, D.; El Ayeb, M.; Rochat, H.; Allen, P.D.; Pessah, I.N.; et al. Chemical synthesis and characterization of maurocalcine, a scorpion toxin that activates $\mathrm{Ca}(2+)$ release channel/ryanodine receptors. FEBS Lett. 2000, 469, 179-185. [CrossRef]

97. Mosbah, A.; Kharrat, R.; Fajloun, Z.; Renisio, J.G.; Blanc, E.; Sabatier, J.M.; El Ayeb, M.; Darbon, H. A new fold in the scorpion toxin family, associated with an activity on a ryanodine-sensitive calcium channel. Proteins 2000, 40, 436-442. [CrossRef]

98. Estève, E.; Mabrouk, K.; Dupuis, A.; Rezgui, S.S.; Altafaj, X.; Grunwald, D.; Platel, J.C.; Andreotti, N.; Marty, I.; Sabatier, J.M.; et al. Transduction of the scorpion toxin maurocalcine into cells. Evidence that the toxin crosses the plasma membrane. J. Biol. Chem. 2005, 280, 12833-12839. [CrossRef] [PubMed]

99. Boisseau, S.; Mabrouk, K.; Ram, N.; Garmy, N.; Collin, V.; Tadmouri, A.; Mikati, M.; Sabatier, J.M.; Ronjat, M.; Fantini, J.; et al. Cell penetration properties of maurocalcine, a natural venom peptide active on the intracellular ryanodine receptor. Biochim. Biophys. Acta 2006, 1758, 308-319. [CrossRef] [PubMed]

100. Aroui, S.; Brahim, S.; De Waard, M.; Bréard, J.; Kenani, A. Efficient induction of apoptosis by doxorubicin coupled to cellpenetrating peptides compared to unconjugated doxorubicin in the human breast cancer cell line MDA-MB 231. Cancer Lett. 2009, 285, 28-38. [CrossRef] [PubMed] 
101. Aroui, S.; Ram, N.; Appaix, F.; Ronjat, M.; Kenani, A.; Pirollet, F.; De Waard, M. Maurocalcine as a non-toxic drug carrier overcomes doxorubicin resistance in the cancer cell line MDA-MB 231. Pharm. Res. 2009, 26, 836-845. [CrossRef]

102. Ram, N.; Weiss, N.; Nogues, T.I.; Aroui, S.; Andreotti, N.; Pirollet, F.; Ronjat, M.; Sabatier, J.M.; Darbon, H.; Jacquemond, V.; et al. Design of a disulfide-less, pharmacologically inert and chemically competent analog of maurocalcine for the efficient transport of impermeant compounds into cells. J. Biol. Chem. 2008, 283, 27048-27056. [CrossRef]

103. Poillot, C.; Bichraoui, H.; Tisseyre, C.; Bahemberae, E.; Andreotti, N.; Sabatier, J.M.; Ronjat, M.; De Waard, M. Small efficient cell-penetrating peptides derived from scorpion toxin maurocalcine. J. Biol. Chem. 2012, 287, 17331-17342. [CrossRef]

104. Poillot, C.; Dridi, K.; Bichraoui, H.; Pêcher, J.; Alphonse, S.; Douzi, B.; Ronjat, M.; Darbon, H.; De Waard, M. D-Maurocalcine, a pharmacologically inert efficient cell-penetrating peptide analogue. J. Biol. Chem. 2010, 285, 34168-34180. [CrossRef]

105. Tisseyre, C.; Bahembera, E.; Dardevet, L.; Sabatier, J.M.; Ronjat, M.; De Waard, M. Cell penetration properties of a highly efficient mini maurocalcine Peptide. Pharmaceuticals 2013, 6, 320-339. [CrossRef]

106. Perret, P.; Ahmadi, M.; Riou, L.; Bacot, S.; Pecher, J.; Poillot, C.; Broisat, A.; Ghezzi, C.; De Waard, M. Biodistribution, Stability and Blood Distribution of the Cell Penetrating Peptide Maurocalcine in Mice. Int. J. Mol. Sci. 2015, 16, 27730-27740. [CrossRef]

107. Aroui, S.; Dardevet, L.; Ajmia, B.W.; de Boisvilliers, M.; Perrin, F.; Laajimi, A.; Boumendjel, A.; Kenani, A.; Muller, J.M.; De Waard, M. A Novel Platinum-Maurocalcine Conjugate Induces Apoptosis of Human Glioblastoma Cells by Acting through the ROS-ERK/AKT-p53 Pathway. Mol. Pharm. 2015, 12, 4336-4348. [CrossRef] [PubMed]

108. Khamehchian, S.; Nikkhah, M.; Madani, R.; Hosseinkhani, S. Enhanced and selective permeability of gold nanoparticles functionalized with cell penetrating peptide derived from maurocalcine animal toxin. J. Biomed. Mater. Res. Part A 2016, 104, 2693-2700. [CrossRef] [PubMed]

109. Gurrola, G.B.; Capes, E.M.; Zamudio, F.Z.; Possani, L.D.; Valdivia, H.H. Imperatoxin A, a Cell-Penetrating Peptide from Scorpion Venom, as a Probe of Ca-Release Channels/Ryanodine Receptors. Pharmaceuticals 2010, 3, 1093-1107. [CrossRef] [PubMed]

110. Schwartz, E.F.; Capes, E.M.; García, D.E.; Zamudio, F.Z.; Fuentes, O.; Possani, L.D.; Valdivia, H.H. Characterization of hadrucalcin, a peptide from Hadrurus gertschi scorpion venom with pharmacological activity on ryanodine receptors. Br. J. Pharmacol. 2009, 157, 392-403. [CrossRef] [PubMed]

111. Zamaleeva, A.I.; Collot, M.; Bahembera, E.; Tisseyre, C.; Rostaing, P.; Yakovlev, A.V.; Oheim, M.; de Waard, M.; Mallet, J.M.; Feltz, A. Cell-penetrating nanobiosensors for pointillistic intracellular Ca2+-transient detection. Nano Lett. 2014, 14, 2994-3001. [CrossRef]

112. King, L.J.V.; Emrick, J.J.; Kelly, M.J.S.; Herzig, V.; King, G.F.; Medzihradszky, K.F.; Julius, D. A Cell-Penetrating Scorpion Toxin Enables Mode-Specific Modulation of TRPA1 and Pain. Cell 2019, 178, 1362-1374. [CrossRef] [PubMed]

113. Lazarovici, P.; Primor, N.; Loew, L.M. Purification and pore-forming activity of two hydrophobic polypeptides from the secretion of the Red Sea Moses sole (Pardachirus marmoratus). J. Biol. Chem. 1986, 261, 16704-16713. [CrossRef]

114. Thompson, S.A.; Tachibana, K.; Nakanishi, K.; Kubota, I. Melittin-Like Peptides from the Shark-Repelling Defense Secretion of the Sole Pardachirus pavoninus. Science 1986, 233, 341-343. [CrossRef] [PubMed]

115. Hsu, J.C.; Lin, L.C.; Tzen, J.T.; Chen, J.Y. Pardaxin-induced apoptosis enhances antitumor activity in HeLa cells. Peptides 2011, 32, 1110-1116. [CrossRef]

116. Kolusheva, S.; Lecht, S.; Derazon, Y.; Jelinek, R.; Lazarovici, P. Pardaxin, a fish toxin peptide interaction with a biomimetic phospholipid/polydiacetylene membrane assay. Peptides 2008, 29, 1620-1625. [CrossRef] [PubMed]

117. Paul, Y.; Weiss, A.; Adermann, K.; Erdmann, G.; Kassebaum, C.; Lazarovici, P.; Hochman, J.; Wellhöner, H. Translocation of acylated pardaxin into cells. FEBS Lett. 1998, 440, 131-134. [CrossRef]

118. Jensen, R.T.; Moody, T.W. Chapter 161-Bombesin-Related Peptides. In Handbook of Biologically Active Peptides, 2nd ed.; Kastin, A.J., Ed.; Academic Press: Boston, MA, USA, 2013; pp. 1188-1196. [CrossRef]

119. König, E.; Emonds, B.O.R.; Shaw, C. The diversity and evolution of anuran skin peptides. Peptides 2015, 63, 96-117. [CrossRef] [PubMed]

120. Valverde, A.; Gutierrez, G.P.; Perez, J.J. Assessment of the conformational profile of bombesin by computational methods. J. Mol. Graph. Model. 2020, 98, 7590. [CrossRef]

121. Mu, L.; Honer, M.; Becaud, J.; Martic, M.; Schubiger, P.A.; Ametamey, S.M.; Stellfeld, T.; Graham, K.; Borkowski, S.; Lehmann, L.; et al. In Vitro and in Vivo Characterization of Novel 18F-Labeled Bombesin Analogues for Targeting GRPR-Positive Tumors. Bioconjugate Chem. 2010, 21, 1864-1871. [CrossRef]

122. Faintuch, B.L.; Oliveira, E.A.; Nunez, E.G.F.; Moro, A.M.; Nanda, P.K.; Smith, C.J. Comparison of two peptide radiotracers for prostate carcinoma targeting. Clinics 2012, 67, 163-170. [CrossRef]

123. Liolios, C.C.; Fragogeorgi, E.A.; Zikos, C.; Loudos, G.; Xanthopoulos, S.; Bouziotis, P.; Petsotas, P.M.; Livaniou, E.; Varvarigou, A.D.; Sivolapenko, G.B. Structural modifications of ${ }^{99} \mathrm{mTc}$-labelled bombesin-like peptides for optimizing pharmacokinetics in prostate tumor targeting. Int. J. Pharm. 2012, 430, 1-17. [CrossRef]

124. Mancilla, J.N.; Flores, F.G.; Cuevas, S.C.; García, O.B.; Gutiérrez, L.M.; Vega, A.E.; Olivé, I.K.; López, C.M.; García, T.E. Multifunctional targeted therapy system based on (99m) Tc/(177) Lu-labeled gold nanoparticles-Tat(49-57)-Lys(3) -bombesin internalized in nuclei of prostate cancer cells. J. Label. Compd. Radiopharm. 2013, 56, 663-671. [CrossRef]

125. Oguiura, N.; Mitake, B.M.; Baptista, R.G. New view on crotamine, a small basic polypeptide myotoxin from South American rattlesnake venom. Toxicon Off. J. Int. Soc. Toxinology 2005, 46, 363-370. [CrossRef] [PubMed] 
126. Oguiura, N.; Collares, M.A.; Furtado, M.F.; Ferrarezzi, H.; Suzuki, H. Intraspecific variation of the crotamine and crotasin genes in Crotalus durissus rattlesnakes. Gene 2009, 446, 35-40. [CrossRef]

127. Tasima, L.J.; -Silva, S.C.; Hatakeyama, D.M.; Nishiduka, E.S.; Tashima, A.K.; Sant Anna, S.S.; Grego, K.F.; Zani, M.K.d.; Azevedo, T.A.M. Crotamine in Crotalus durissus: Distribution according to subspecies and geographic origin, in captivity or nature. J. Venom. Anim. Toxins Incl. Trop. Dis. 2020, 26. [CrossRef] [PubMed]

128. Chang, C.C.; Tseng, K.H. Effect of crotamine, a toxin of South American rattlesnake venom, on the sodium channel of murine skeletal muscle. Br. J. Pharmacol. 1978, 63, 551-559. [CrossRef]

129. Rizzi, C.T.; Souza, C.d.J.L.; Schiavon, E.; Cassola, A.C.; Wanke, E.; Troncone, L.R. Crotamine inhibits preferentially fast-twitching muscles but is inactive on sodium channels. Toxicon Off. J. Int. Soc. Toxinology 2007, 50, 553-562. [CrossRef] [PubMed]

130. Ownby, C.L.; Aird, S.D.; Kaiser, I.I. Physiological and immunological properties of small myotoxins from the venom of the midget faded rattlesnake (Crotalus viridis concolor). Toxicon Off. J. Int. Soc. Toxinology 1988, 26, 319-323. [CrossRef]

131. Torres, A.M.; Kuchel, P.W. The beta-defensin-fold family of polypeptides. Toxicon Off. J. Int. Soc. Toxinology 2004, 44, 581-588. [CrossRef]

132. Yeaman, M.R.; Yount, N.Y. Unifying themes in host defence effector polypeptides. Nat. Rev. Microbiol. 2007, 5, 727-740. [CrossRef]

133. Sieber, M.; Bosch, B.; Hanke, W.; de Lima, F.V.M. Membrane-modifying properties of crotamine, a small peptide-toxin from Crotalus durissus terifficus venom. Biochim. Biophys. Acta 2014, 1840, 945-950. [CrossRef]

134. de Lima, V.M.; Spencer, P.; Hanke, W. Interaction of small cationic peptides with intact basement membranes. A study using intrinsic optical signals of chick retinas. Curr. Med. Chem. 2014, 21, 1458-1466. [CrossRef]

135. Falcao, C.B.; Baptista, R.G. Crotamine and crotalicidin, membrane active peptides from Crotalus durissus terrificus rattlesnake venom and their structurally-minimized fragments for applications in medicine and biotechnology. Peptides 2020, $126,234$. [CrossRef] [PubMed]

136. Kerkis, I.; Silva Fde, S.; Pereira, A.; Kerkis, A.; Baptista, R.G. Biological versatility of crotamine-a cationic peptide from the venom of a South American rattlesnake. Expert Opin. Investig. Drugs 2010, 19, 1515-1525. [CrossRef] [PubMed]

137. Baptista, R.G.; Kerkis, I. Crotamine, a small basic polypeptide myotoxin from rattlesnake venom with cell-penetrating properties. Curr. Pharm. Des. 2011, 17, 4351-4361. [CrossRef] [PubMed]

138. Kerkis, I.; Hayashi, M.A.; da Silva, P.A.R.; Pereira, A.; De Júnior, S.P.L.; Zaharenko, A.J.; Baptista, R.G.; Kerkis, A.; Yamane, T. State of the art in the studies on crotamine, a cell penetrating peptide from South American rattlesnake. BioMed Res. Int. 2014, 2014, 5985. [CrossRef]

139. Kerkis, A.; Kerkis, I.; Baptista, R.G.; Oliveira, E.B.; Morgante, V.A.M.; Pereira, L.V.; Yamane, T. Crotamine is a novel cellpenetrating protein from the venom of rattlesnake Crotalus durissus terrificus. FASEB J. Off. Publ. Fed. Am. Soc. Exp. Biol. 2004, 18, 1407-1409. [CrossRef]

140. Nascimento, F.D.; Hayashi, M.A.; Kerkis, A.; Oliveira, V.; Oliveira, E.B.; Baptista, R.G.; Nader, H.B.; Yamane, T.; Tersariol, I.L.; Kerkis, I. Crotamine mediates gene delivery into cells through the binding to heparan sulfate proteoglycans. J. Biol. Chem. 2007, 282, 21349-21360. [CrossRef]

141. Chen, P.C.; Hayashi, M.A.; Oliveira, E.B.; Karpel, R.L. DNA-interactive properties of crotamine, a cell-penetrating polypeptide and a potential drug carrier. PLoS ONE 2012, 7, 8913. [CrossRef]

142. Pereira, A.; Kerkis, A.; Hayashi, M.A.; Pereira, A.S.; Silva, F.S.; Oliveira, E.B.; da Silva, P.A.R.; Yamane, T.; Baptista, R.G.; Kerkis, I. Crotamine toxicity and efficacy in mouse models of melanoma. Expert Opin. Investig. Drugs 2011, 20, 1189-1200. [CrossRef]

143. Lisboa, M.N.C.; Sciani, J.M.; da Silva, B.P.A.R.; Kerkis, I. Co-Localization of Crotamine with Internal Membranes and Accentuated Accumulation in Tumor Cells. Molecules 2018, 23, 968. [CrossRef]

144. Hayashi, M.A.; Nascimento, F.D.; Kerkis, A.; Oliveira, V.; Oliveira, E.B.; Pereira, A.; Baptista, R.G.; Nader, H.B.; Yamane, T.; Kerkis, I.; et al. Cytotoxic effects of crotamine are mediated through lysosomal membrane permeabilization. Toxicon Off. J. Int. Soc. Toxinology 2008, 52, 508-517. [CrossRef]

145. Ponnappan, N.; Budagavi, D.P.; Chugh, A. CyLoP-1: Membrane-active peptide with cell-penetrating and antimicrobial properties. Biochim. Biophys. Acta Biomembr. 2017, 1859, 167-176. [CrossRef]

146. Baptista, R.G.; de la Torre, B.G.; Andreu, D. A novel cell-penetrating peptide sequence derived by structural minimization of a snake toxin exhibits preferential nucleolar localization. J. Med. Chem. 2008, 51, 7041-7044. [CrossRef]

147. Baptista, R.G.; de la Torre, B.G.; Andreu, D. Insights into the uptake mechanism of NrTP, a cell-penetrating peptide preferentially targeting the nucleolus of tumour cells. Chem. Biol. Drug Des. 2012, 79, 907-915. [CrossRef]

148. Rodrigues, M.; de la Torre, B.G.; Baptista, R.G.; Santos, N.C.; Andreu, D. Efficient cellular delivery of beta-galactosidase mediated by NrTPs, a new family of cell-penetrating peptides. Bioconjug. Chem. 2011, 22, 2339-2344. [CrossRef] [PubMed]

149. Rodrigues, M.; Santos, A.; de la Torre, B.G.; Baptista, R.G.; Andreu, D.; Santos, N.C. Molecular characterization of the interaction of crotamine-derived nucleolar targeting peptides with lipid membranes. Biochim. Biophys. Acta 2012, 1818, 2707-2717. [CrossRef] [PubMed]

150. Rodrigues, M.; de la Torre, B.G.; Andreu, D.; Santos, N.C. Kinetic uptake profiles of cell penetrating peptides in lymphocytes and monocytes. Biochim. Biophys. Acta 2013, 1830, 4554-4563. [CrossRef] [PubMed]

151. Rodrigues, M.; Andreu, D.; Santos, N.C. Uptake and cellular distribution of nucleolar targeting peptides (NrTPs) in different cell types. Biopolymers 2015, 104, 101-109. [CrossRef] 
152. Tansi, F.L.; Filatova, M.P.; Koroev, D.O.; Volpina, O.M.; Lange, S.; Schumann, C.; Teichgräber, U.K.; Reissmann, S.; Hilger, I. New generation CPPs show distinct selectivity for cancer and noncancer cells. J. Cell. Biochem. 2019, 120, 6528-6541. [CrossRef]

153. Falcao, C.B.; de La Torre, B.G.; Peinado, P.C.; Barron, A.E.; Andreu, D.; Baptista, R.G. Vipericidins: A novel family of cathelicidinrelated peptides from the venom gland of South American pit vipers. Amino Acids 2014, 46, 2561-2571. [CrossRef]

154. Sørensen, O.E.; Follin, P.; Johnsen, A.H.; Calafat, J.; Tjabringa, G.S.; Hiemstra, P.S.; Borregaard, N. Human cathelicidin, hCAP-18, is processed to the antimicrobial peptide LL-37 by extracellular cleavage with proteinase 3. Blood 2001, 97, 3951-3959. [CrossRef]

155. Peinado, P.C.; Defaus, S.; Andreu, D. Hitchhiking with Nature: Snake Venom Peptides to Fight Cancer and Superbugs. Toxins 2020, 12, 255. [CrossRef]

156. Baptista, R.G. Vipericidins, Snake Venom Cathelicidin-Related Peptides, in the Milieu of Reptilian Antimicrobial Polypeptides. Snake Venoms 2015, 1-25. [CrossRef]

157. van Hoek, M.L. Antimicrobial peptides in reptiles. Pharmaceuticals 2014, 7, 723-753. [CrossRef] [PubMed]

158. Zhao, F.; Lan, X.Q.; Du, Y.; Chen, P.Y.; Zhao, J.; Zhao, F.; Lee, W.H.; Zhang, Y. King cobra peptide OH-CATH30 as a potential candidate drug through clinic drug-resistant isolates. Zool. Res. 2018, 39, 87-96. [CrossRef] [PubMed]

159. Xing, M.; Ji, M.; Hu, J.; Zhu, T.; Chen, Y.; Bai, X.; Mwangi, J.; Mo, G.; Lai, R.; Jin, L. Snake Cathelicidin Derived Peptide Inhibits Zika Virus Infection. Front. Microbiol. 2020, 11. [CrossRef]

160. Zhang, H.; Xia, X.; Han, F.; Jiang, Q.; Rong, Y.; Song, D.; Wang, Y. Cathelicidin-BF, a Novel Antimicrobial Peptide from Bungarus fasciatus, Attenuates Disease in a Dextran Sulfate Sodium Model of Colitis. Mol. Pharm. 2015, 12, 1648-1661. [CrossRef]

161. Wei, L.; Gao, J.; Zhang, S.; Wu, S.; Xie, Z.; Ling, G.; Kuang, Y.Q.; Yang, Y.; Yu, H.; Wang, Y. Identification and Characterization of the First Cathelicidin from Sea Snakes with Potent Antimicrobial and Anti-inflammatory Activity and Special Mechanism. J. Biol. Chem. 2015, 290, 16633-16652. [CrossRef] [PubMed]

162. Carlile, S.R.; Shiels, J.; Kerrigan, L.; Delaney, R.; Megaw, J.; Gilmore, B.F.; Weldon, S.; Dalton, J.P.; Taggart, C.C. Sea snake cathelicidin (Hc-cath) exerts a protective effect in mouse models of lung inflammation and infection. Sci. Rep. 2019, 9, 6071. [CrossRef]

163. Girão, V.P.R.N.; Falcão, C.B.; Rocha, I.; Lucena, H.M.R.; Costa, F.H.F.; Baptista, R.G. Antiviral Activity of Ctn[15-34], A Cathelicidin-Derived Eicosapeptide, Against Infectious Myonecrosis Virus in Litopenaeus vannamei Primary Hemocyte Cultures. Food Environ. Virol. 2017, 9, 277-286. [CrossRef]

164. Amer, L.S.; Bishop, B.M.; van Hoek, M.L. Antimicrobial and antibiofilm activity of cathelicidins and short, synthetic peptides against Francisella. Biochem. Biophys. Res. Commun. 2010, 396, 246-251. [CrossRef]

165. de Latour, F.A.; Amer, L.S.; Papanstasiou, E.A.; Bishop, B.M.; van Hoek, M.L. Antimicrobial activity of the Naja atra cathelicidin and related small peptides. Biochem. Biophys. Res. Commun. 2010, 396, 825-830. [CrossRef]

166. Chen, W.; Yang, B.; Zhou, H.; Sun, L.; Dou, J.; Qian, H.; Huang, W.; Mei, Y.; Han, J. Structure-activity relationships of a snake cathelicidin-related peptide, BF-15. Peptides 2011, 32, 2497-2503. [CrossRef]

167. de Aguiar, F.L.L.; Cavalcante, C.; Dos Fontenelle, S.R.O.; Falcão, C.B.; Andreu, D.; Baptista, R.G. The antiproliferative peptide Ctn[15-34] is active against multidrug-resistant yeasts Candida albicans and Cryptococcus neoformans. J. Appl. Microbiol. 2020, 128, 414-425. [CrossRef]

168. Zhou, H.; Dou, J.; Wang, J.; Chen, L.; Wang, H.; Zhou, W.; Li, Y.; Zhou, C. The antibacterial activity of BF-30 in vitro and in infected burned rats is through interference with cytoplasmic membrane integrity. Peptides 2011, 32, 1131-1138. [CrossRef]

169. Juba, M.L.; Porter, D.K.; Williams, E.H.; Rodriguez, C.A.; Barksdale, S.M.; Bishop, B.M. Helical cationic antimicrobial peptide length and its impact on membrane disruption. Biochim. Biophys. Acta 2015, 1848, 1081-1091. [CrossRef] [PubMed]

170. Cavalcante, C.S.P.; de Aguiar, F.L.L.; Fontenelle, R.O.S.; de Menezes, R.; Martins, A.M.C.; Falcão, C.B.; Andreu, D.; Baptista, R.G. Insights into the candidacidal mechanism of Ctn[15-34] - a carboxyl-terminal, crotalicidin-derived peptide related to cathelicidins. J. Med Microbiol. 2018, 67, 129-138. [CrossRef]

171. Peinado, P.C.; Dias, S.A.; Domingues, M.M.; Benfield, A.H.; Freire, J.M.; Baptista, R.G.; Gaspar, D.; Castanho, M.; Craik, D.J.; Henriques, S.T.; et al. Mechanisms of bacterial membrane permeabilization by crotalicidin (Ctn) and its fragment Ctn(15-34), antimicrobial peptides from rattlesnake venom. J. Biol. Chem. 2018, 293, 1536-1549. [CrossRef] [PubMed]

172. Aguiar, F.L.L.; Santos, N.C.; de Cavalcante, P.C.S.; Andreu, D.; Baptista, G.R.; Gonçalves, S. Antibiofilm Activity on Candida albicans and Mechanism of Action on Biomembrane Models of the Antimicrobial Peptide Ctn[15-34]. Int. J. Mol. Sci. 2020, 21, 8339. [CrossRef] [PubMed]

173. Falcao, C.B.; Peinado, P.C.; de la Torre, B.G.; Mayol, X.; Carreras, Z.H.; Jiménez, M.; Baptista, R.G.; Andreu, D. Structural Dissection of Crotalicidin, a Rattlesnake Venom Cathelicidin, Retrieves a Fragment with Antimicrobial and Antitumor Activity. J. Med. Chem. 2015, 58, 8553-8563. [CrossRef]

174. Wang, L.; Chan, J.Y.; Rêgo, J.V.; Chong, C.M.; Ai, N.; Falcão, C.B.; Baptista, R.G.; Lee, S.M. Rhodamine B-conjugated encrypted vipericidin nonapeptide is a potent toxin to zebrafish and associated with in vitro cytotoxicity. Biochim. Biophys. Acta 2015, 1850, 1253-1260. [CrossRef] [PubMed]

175. Hao, Q.; Wang, H.; Wang, J.; Dou, J.; Zhang, M.; Zhou, W.; Zhou, C. Effective antimicrobial activity of Cbf-K16 and Cbf-A7A13 against NDM-1-carrying Escherichia coli by DNA binding after penetrating the cytoplasmic membrane in vitro. J. Pept. Sci. 2013, 19, 173-180. [CrossRef] [PubMed]

176. Peinado, P.C.; Valle, J.; Freire, J.M.; Andreu, D. Tumor Cell Attack by Crotalicidin (Ctn) and Its Fragment Ctn[15-34]: Insights into Their Dual Membranolytic and Intracellular Targeting Mechanism. ACS Chem. Biol. 2020, 15, 2945-2957. [CrossRef] [PubMed] 
177. Dubovskii, P.V.; Konshina, A.G.; Efremov, R.G. Cobra cardiotoxins: Membrane interactions and pharmacological potential. Curr. Med. Chem. 2014, 21, 270-287. [CrossRef] [PubMed]

178. Chiou, J.T.; Shi, Y.J.; Wang, L.J.; Huang, C.H.; Lee, Y.C.; Chang, L.S. Naja atra Cardiotoxin 3 Elicits Autophagy and Apoptosis in U937 Human Leukemia Cells through the Ca(2+)/PP2A/AMPK Axis. Toxins 2019, 11, 527. [CrossRef]

179. Feofanov, A.V.; Sharonov, G.V.; Astapova, M.V.; Rodionov, D.I.; Utkin, Y.N.; Arseniev, A.S. Cancer cell injury by cytotoxins from cobra venom is mediated through lysosomal damage. Biochem. J. 2005, 390, 11-18. [CrossRef]

180. Zhang, B.; Li, F.; Chen, Z.; Shrivastava, I.H.; Gasanoff, E.S.; Dagda, R.K. Naja mossambica mossambica Cobra Cardiotoxin Targets Mitochondria to Disrupt Mitochondrial Membrane Structure and Function. Toxins 2019, 11, 152. [CrossRef]

181. Ambra, D.I.; Lauritano, C. A Review of Toxins from Cnidaria. Mar. Drugs 2020, 18, 507. [CrossRef]

182. Lee, G.; Bae, H. Bee Venom Phospholipase A2: Yesterday's Enemy Becomes Today's Friend. Toxins 2016, 8, 48. [CrossRef]

183. Krayem, N.; Gargouri, Y. Scorpion venom phospholipases A(2): A minireview. Toxicon Off. J. Int. Soc. Toxinology 2020, 184, 48-54. [CrossRef]

184. Zambelli, V.O.; Picolo, G.; Fernandes, C.A.H.; Fontes, M.R.M.; Cury, Y. Secreted Phospholipases $A_{2}$ from Animal Venoms in Pain and Analgesia. Toxins 2017, 9, 406. [CrossRef]

185. Mendes, B.; Almeida, J.R.; Vale, N.; Gomes, P.; Gadelha, F.R.; Da Silva, S.L.; Miguel, D.C. Potential use of 13-mer peptides based on phospholipase and oligoarginine as leishmanicidal agents. Comp. Biochem. Physiol. Toxicol. Pharmacol. CBP 2019, 226, 108612. [CrossRef]

186. Lameu, C.; Neiva, M.; Hayashi, M. Venom Bradykinin-Related Peptides (BRPs) and Its Multiple Biological Roles; IntechOpen Limited: London, UK, 2013; Volume 5, pp. 119-151. [CrossRef]

187. Sciani, J.M.; Vigerelli, H.; Costa, A.S.; Câmara, D.A.; Junior, P.L.; Pimenta, D.C. An unexpected cell-penetrating peptide from Bothrops jararaca venom identified through a novel size exclusion chromatography screening. J. Pept. Sci. Off. Publ. Eur. Pept. Soc. 2017, 23, 68-76. [CrossRef]

188. Alouf, J.E. Pore-Forming Bacterial Protein Toxins: An Overview. In Pore-Forming Toxins; van der Goot, F.G., Ed.; Springer: Berlin/Heidelberg, Germany, 2001; pp. 1-14. [CrossRef]

189. Barth, H.; Aktories, K.; Popoff, M.R.; Stiles, B.G. Binary bacterial toxins: Biochemistry, biology and applications of common Clostridium and Bacillus proteins. Microbiol. Mol. Biol. Rev. 2004, 68, 373-402. [CrossRef] [PubMed]

190. Pluzhnikov, K.; Nosyreva, E.; Shevchenko, L.; Kokoz, Y.; Schmalz, D.; Hucho, F.; Grishin, E. Analysis of ectatomin action on cell membranes. Eur. J. Biochem. 1999, 262, 501-506. [CrossRef]

191. Nentwig, K.L. Antimicrobial and cytolytic peptides of venomous arthropods. Cell. Mol. Life Sci. CMLS 2003, 60, 2651-2668. [CrossRef]

192. Vassilevski, A.A.; Kozlov, S.A.; Samsonova, O.V.; Egorova, N.S.; Karpunin, D.V.; Pluzhnikov, K.A.; Feofanov, A.V.; Grishin, E.V. Cyto-insectotoxins, a novel class of cytolytic and insecticidal peptides from spider venom. Biochem. J. 2008, 411, 687-696. [CrossRef]

193. Anderluh, G.; Sepčić, K.; Turk, T.; Maček, P. Cytolytic proteins from cnidarians - an overview. Acta Chim. Slov. 2011, 58, 724-729. [PubMed]

194. Podobnik, M.; Anderluh, G. Pore-forming toxins in Cnidaria. Semin. Cell Dev. Biol. 2017, 72, 133-141. [CrossRef]

195. Huang, C.; Morlighem, J.R.; Zhou, H.; Lima, É.P.; Gomes, P.B.; Cai, J.; Lou, I.; Pérez, C.D.; Lee, S.M.; Baptista, R.G. The Transcriptome of the Zoanthid Protopalythoa variabilis (Cnidaria, Anthozoa) Predicts a Basal Repertoire of Toxin-like and Venom-Auxiliary Polypeptides. Genome Biol. Evol. 2016, 8, 3045-3064. [CrossRef]

196. Galloso, M.H.; Pedrera, L.; Ros, U. Pore-forming proteins: From defense factors to endogenous executors of cell death. Chem. Phys. Lipids 2020, 2020, 5026. [CrossRef]

197. Geny, B.; Popoff, M.R. Bacterial protein toxins and lipids: Pore formation or toxin entry into cells. Biol. Cell 2006, 98, 667-678. [CrossRef]

198. Fabbrini, M.S.; Katayama, M.; Nakase, I.; Vago, R. Plant Ribosome-Inactivating Proteins: Progesses, Challenges and Biotechnological Applications (and a Few Digressions). Toxins 2017, 9, 314. [CrossRef] [PubMed]

199. Ladokhin, A.S. Cellular Entry of Binary and Pore-Forming Bacterial Toxins. Toxins 2018, 10, 11. [CrossRef] [PubMed]

200. Liberati, A.; Altman, D.G.; Tetzlaff, J.; Mulrow, C.; Gøtzsche, P.C.; Ioannidis, J.P.A.; Clarke, M.; Devereaux, P.J.; Kleijnen, J.; Moher, D. The PRISMA Statement for Reporting Systematic Reviews and Meta-Analyses of Studies That Evaluate Health Care Interventions: Explanation and Elaboration. PLoS Med. 2009, 6, 100. [CrossRef] [PubMed] 